\title{
Fission Gas Monitoring System Efficiency Calibration Summary Report
}

\section{Edward L Reber}

May 2020

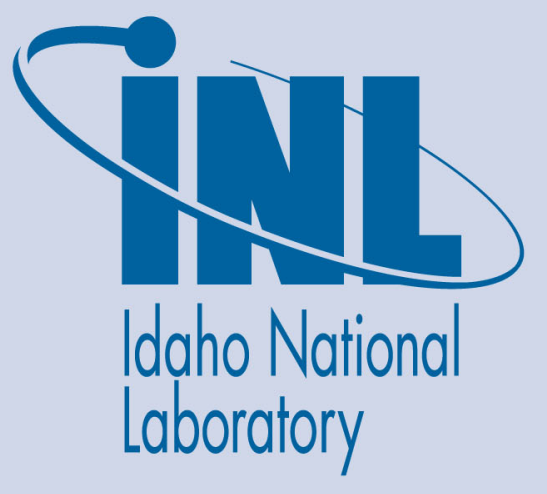

The INL is a U.S. Department of Energy National Laboratory operated by Battelle Energy Alliance 


\title{
Fission Gas Monitoring System Efficiency Calibration Summary Report
}

\author{
Edward L Reber \\ May 2020 \\ Idaho National Laboratory \\ Idaho Falls, Idaho 83415 \\ http://www.inl.gov \\ Prepared for the \\ U.S. Department of Energy \\ Under DOE Idaho Operations Office \\ Contract DE-AC07-05ID14517
}


Fission Gas Monitoring System Efficiency Calibration Summary Report

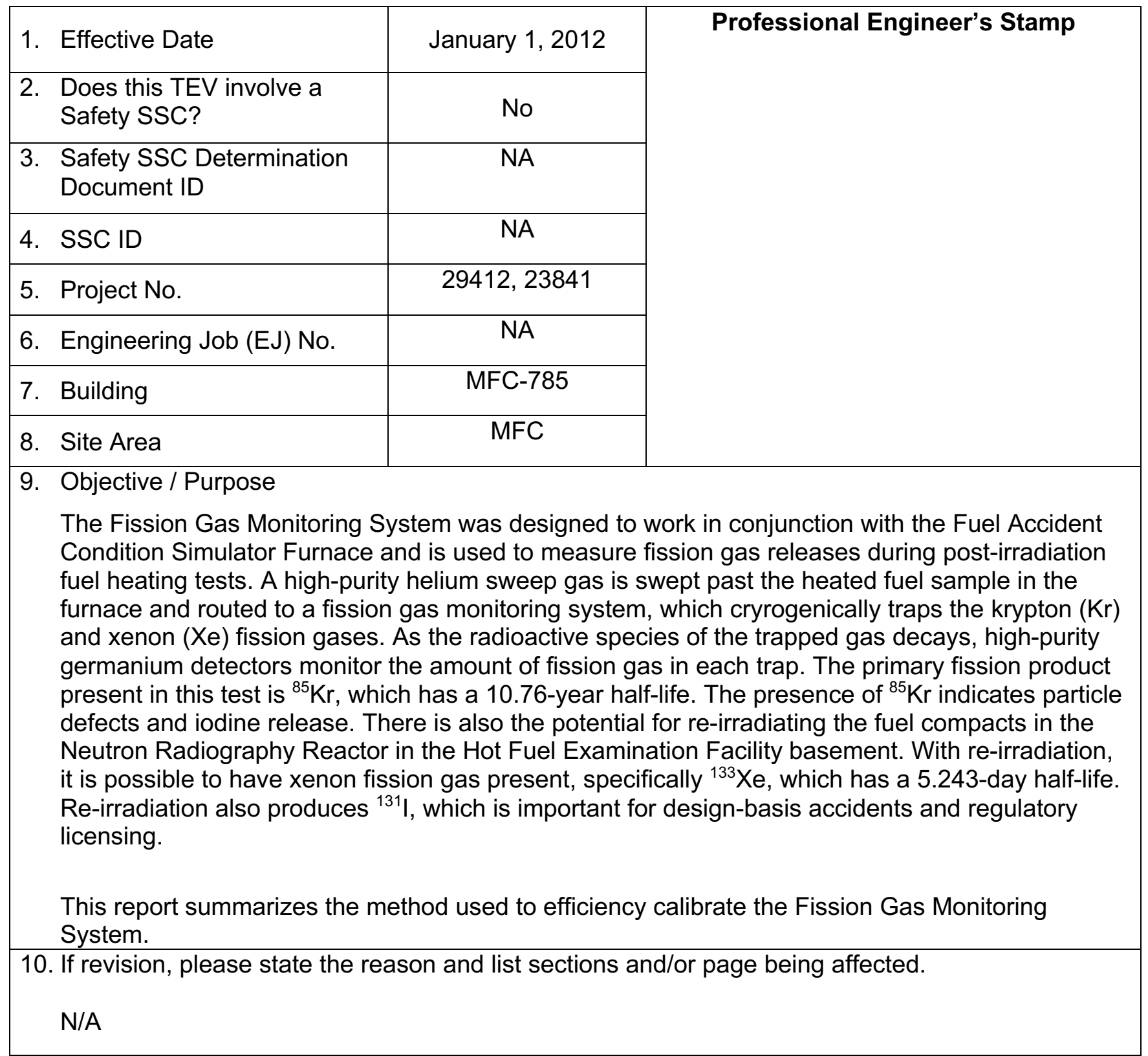


Fission Gas Monitoring System Efficiency Calibration Summary Report

\section{Conclusion / Recommendations}

The FGMS was calibrated with five certified standards, ranging from 0.924 to $390.8 \mu \mathrm{Ci}$. This range of activity simulated prospective Advanced Gas Reactor (AGR)-1 fuel failure within the FACS furnace, ranging from an inventory of one failed particle to many failed particles. HPGe detector responses were obtained at three different detector-to-trap differences (i.e., height), with the corresponding collimation shutter width ranging from 0.5 to $11.0 \mathrm{~cm}$. An efficiency calibration curve was generated for each configuration. These measurements enabled the FGMS team to quantify the activity of the fission gas captured within the FGMS CTs.

Efficiency measurements were acquired from December 2009 to November 2011 and performed at the mockup shop (FCF) and HFEF. The FGMS now permanently resides at HFEF. Efficiency measurements were performed during this extended time span because of certified standard availability, budget constraints, facility shutdowns, and other parameters outside the FGMS support team's control.

Measurements provided in this report satisfy the requirements for the AGR-1 fuel post-irradiation examination experiment series. It is recommended that periodic efficiency measurements are performed to ensure that increased usage of the cold traps does not affect their efficiencies. 


\section{CONTENTS}

PROJECT ROLES AND RESPONSIBILITIES................................................................4

SCOPE AND BRIEF DESCRIPTION ......................................................................5

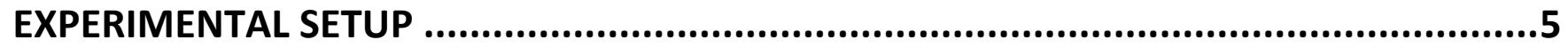

SOURCE TRANSFER...............................................................................8

EFFICIENCY MEASUREMENT AND COMPARISON .............................................14

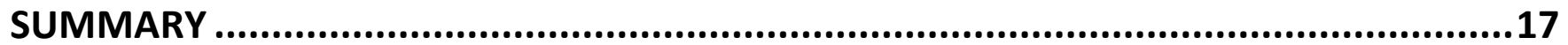

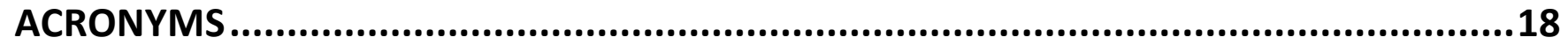

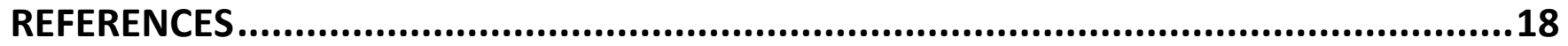

\section{APPENDIXES}

- Appendix A - FGMS Tabular Efficiency Results

- Appendix B - Calculation of Efficiency and Its Uncertainty

- Appendix C - Radionuclide Source Certificate of Calibration 
Fission Gas Monitoring System Efficiency Calibration Summary Report

\section{PROJECT ROLES AND RESPONSIBILITIES}

\begin{tabular}{|c|c|c|c|}
\hline Project Role & Name & Organization & Pages Covered (if applicable) \\
\hline Performer & Edward Reber & C620 & ----- \\
\hline Checker $^{a}$ & Ryan Fronk & C620 & ----- \\
\hline Independent Reviewer ${ }^{b}$ & Michael Reichenberger & B633 & $\begin{array}{ll}---- \\
\end{array}$ \\
\hline CUI Reviewer ${ }^{\mathrm{C}}$ & ----- & ----- & ----- \\
\hline Manager $^{d}$ & ----- & ----- & ----- \\
\hline Requestor $^{\mathrm{ef}}$ & Dawn Scates & C620 & $\begin{array}{ll}---- \\
--1\end{array}$ \\
\hline Nuclear Safety $^{f}$ & $\mathrm{~N} / \mathrm{A}$ & ---- & ----- \\
\hline Document Owner ${ }^{f}$ & Dawn Scates & C620 & $\begin{array}{ll}---- \\
\end{array}$ \\
\hline Reviewer $^{f}$ & Paul Demkowicz & $\mathrm{C} 600$ & $\begin{array}{ll}---- \\
\end{array}$ \\
\hline Quality Engineer ${ }^{f}$ & Michelle Sharp & $\mathrm{H} 330$ & \\
\hline
\end{tabular}

\section{Responsibilities:}

a. Confirmation of completeness, mathematical accuracy, correctness of data, and appropriateness of assumptions.

b. Concurrence of method or approach. See definition, LWP-10106.

c. Concurrence with the document's markings in accordance with LWP-11202.

d. Concurrence of procedure compliance. Concurrence with method/approach and conclusion.

e. Authorizes commencement of work of the engineering deliverable. See Appendix A.

f. Concurrence with the document's assumptions and input information. See definition of "acceptance," LWP10200.

NOTE: Delete or mark "N/A" for project roles not engaged. Include ALL personnel and their roles listed above in the eCR system. The list of the roles above is not all inclusive. If needed, the list can be extended or reduced. 


\section{SCOPE AND BRIEF DESCRIPTION}

Efficiency calibration of the Fission Gas Monitoring System (FGMS) consists of first loading the liquidnitrogen cooled cold trap (CT) with a ${ }^{133} \mathrm{Xe}(81 \mathrm{keV})$ and/or ${ }^{85} \mathrm{Kr}(514 \mathrm{keV})$ gas source. The source is then counted with the detector at various distances measured from the bottom of the CT, and with various collimator shutter widths. The thirteen different configurations measured are shown in Table 1. Note that, when the detector is against the bottom of the CT at a cold trap-detector distance of $0 \mathrm{~cm}$, the detector is between the collimator shutters; therefore, the tungsten collimator must be completely open to $11 \mathrm{~cm}$ in width.

Table 1. FGMS configurations - cold-trap-to-detector distance and collimator shutter width.

\begin{tabular}{|c|c|c|c|c|c|c|c|}
\hline $\begin{array}{c}\text { Trap-Det. } \\
\text { Distance }\end{array}$ & $\begin{array}{c}\text { Collimator } \\
\text { Width }\end{array}$ & $\begin{array}{c}\text { Trap-Det. } \\
\text { Distance }\end{array}$ & $\begin{array}{c}\text { Collimator } \\
\text { Width }\end{array}$ & $\begin{array}{c}\text { Trap-Det. } \\
\text { Distance }\end{array}$ & $\begin{array}{c}\text { Collimator } \\
\text { Width }\end{array}$ \\
\hline 0.0 & 11.0 & & 3.1 & 11.0 & 6.2 & 11.0 \\
\hline & & & 3.1 & 2.5 & & 6.2 & 2.5 \\
\hline & & 3.1 & 2.0 & 6.2 & 2.0 \\
\hline \multicolumn{2}{|l}{$\begin{array}{l}\text { All values are in } \\
\text { centimeters }\end{array}$} & & 3.1 & 1.5 & 6.2 & 1.5 \\
\hline & & 3.1 & 1.0 & 6.2 & 1.0 \\
\hline
\end{tabular}

To simulate the actual fission products released from fuel particles in the Fuel Accident Condition Simulator (FACS) furnace, the furnace was first heated to $1600^{\circ} \mathrm{C}$. Then a certified gas standard source was injected into it. The source was injected using a pure helium sweep gas, which flowed through the source container carrying the source to the furnace. The helium then flowed through the furnace, through tubing, and passed through the CT, where the source froze out. The freezing points for the nuclide involved are xenon $\left(-112^{\circ} \mathrm{C}\right)$, krypton $\left(-157^{\circ} \mathrm{C}\right)$, and helium $\left(-272^{\circ} \mathrm{C}\right)$, and nitrogen is liquid between $-210^{\circ} \mathrm{C}$ and $-196^{\circ} \mathrm{C}$. Liquid nitrogen is cold enough to freeze xenon and krypton, but not helium. The helium flow continued to the facility exhaust. The counts per second (CPS) recorded by the detector were monitored, and, when the CPS plateaued, the transfer was deemed complete. Once the source was completely transferred to the CT, the valves to the CT were closed, and the CT was maintained at liquid nitrogen temperature until the efficiency measurements were complete. If the CT warms up at all, the source drifts, and efficiencies calculated from any future measurements would be inaccurate.

This document contains a summary of information recorded in two physical INL registered laboratory notebooks ${ }^{2,3}$.

\section{EXPERIMENTAL SETUP}

The helium sweep gas that passes through the FACS furnace is routed through a particulate filter before exiting the hot cell and being routed to the FGMS. The FGMS was designed to measure ${ }^{85} \mathrm{Kr}$, ${ }^{133} \mathrm{Xe}$, and other radioactive fission gases released from the fuel. The FGMS consists of two independent measurement systems. Each system contains a charcoal CT, shielding, a collimator, and 
a high-purity germanium detector (HPGe). Figure 1 shows a schematic of the FGMS. FGMS \#1 refers to the primary system into which the fission gas first flows and is then captured in Cold Trap \#1 (CT\#1), and HPGe detector P1 monitors CT\#1 for gamma rays emitted from the sources. FGMS \#2 refers to the secondary system containing Cold Trap \#2 (CT\#2), which is monitored by HPGe detector P2. Helium from the FACS furnace can be routed to either system or through first one system and then the other. The normal operation configuration is when the helium flows through CT\#1, then CT\#2, and finally to facility exhaust. This configuration enables confirmation that the fission gas is completely captured in CT\#1, through observation that none of the fission gas is detected in CT\#2. This redundant system was primarily developed in case the primary CT failed due to saturation, being plugged from impurities, or detector failure. In any case, helium flow could be routed to the second CT without interrupting the FACS experiment. Also, if the primary system fails, any radioactive sample can be transferred to the secondary system.

Additionally, a replaceable supplemental trap, referred to as a U-trap, may be placed right before the facility exhaust. This supplemental trap may be used to capture the source or sample for future use.

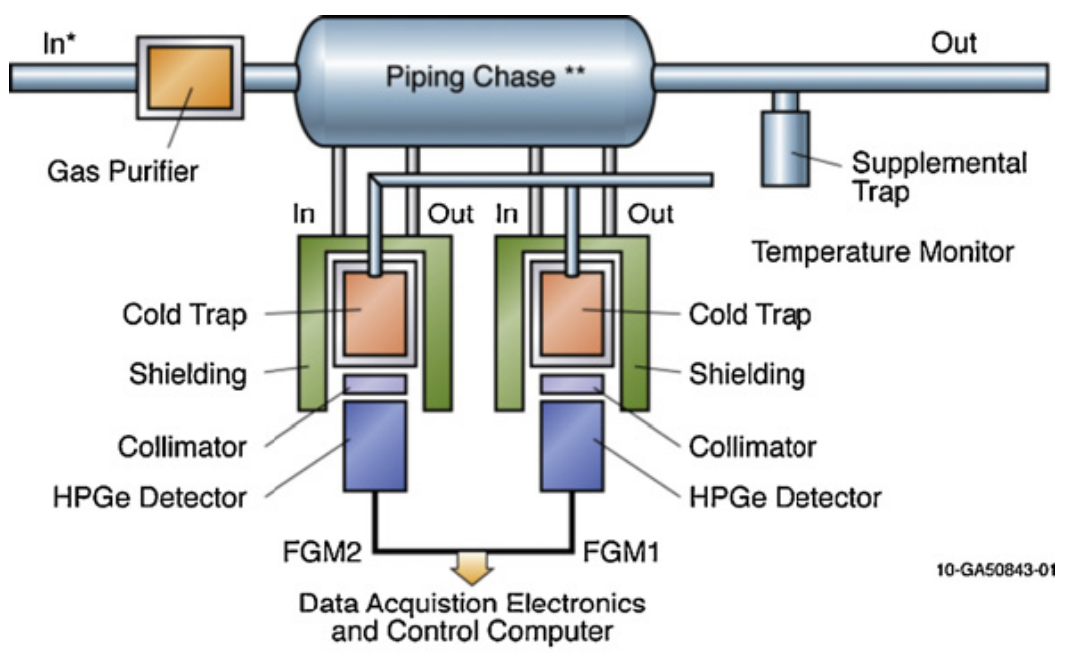

* Fission gas leaving the furnace and the hot cell.

** The piping chase is support for the inlet and outlet gas lines for the fission gas and the LN supply

Figure 1. Schematic diagram of the Fission Gas Monitoring System.

Figure 2 shows an FGMS assembly. The assembly consists of an upper and lower lead (Pb) shield, HPGe detector, tungsten shutter system, and CT. A 10\% closed-end coaxial HPGe detector with an upward-looking cryostat configuration is mounted on an adjustable lift cart. The detector cryostat is inserted into the lower $\mathrm{Pb}$ shield (4-cm thick), is positioned using machined spacers, and is then locked into place. Figure 3 shows a bird's-eye view of the lower $\mathrm{Pb}$ shield, which runs the length of the detector's crystal, even at the lowest position. The detector can be manually positioned by lowering the cart to detector-CT distances of $0 \mathrm{~cm}, 3.1 \mathrm{~cm}$, or $6.2 \mathrm{~cm}$. These are the distance between the top of the detector's cryostat aluminum cover and the bottom of the CT. The detector will be lowered away from the CT if the detector's deadtime becomes too high (> 25\%). In addition to lowering the detector, a shutter system (i.e., collimator) is available to reduce the count rate of the detector. Figure 3 shows the collimator shutters completely open (i.e., $11 \mathrm{~cm}$ wide). The collimator shutters are $3.1-\mathrm{cm}$ thick and 
made of tungsten. When the detector-CT distance is at 3.1 or $6.2 \mathrm{~cm}$, the automatic shutter system engages. If the detector's CPS reaches an adjustable threshold level, the collimator shutters automatically close to a preset width, preventing the detector's deadtime from becoming too high to record accurate data, while still enabling the detector to continue data collection. To avoid damage to the detector, this feature disengages when the detector is at the $0-\mathrm{cm}$ position, putting it between the collimator shutters. The collimator shutter's allowed opening widths are $0.5,1.0,1.5,2.0,2.5$, and $11.0 \mathrm{~cm}$. Table 1 lists the thirteen detector distance-collimator configurations for which efficiency measurements were obtained.

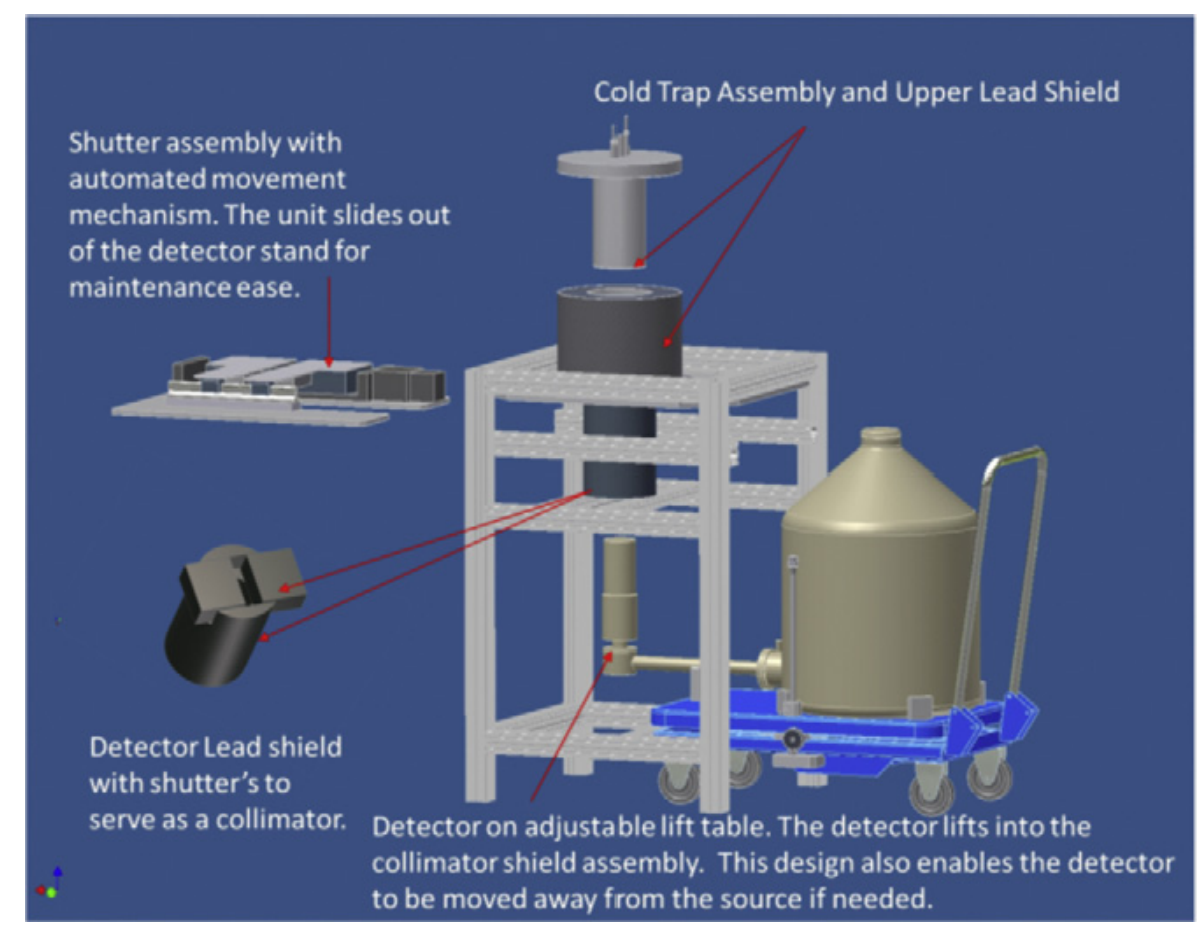

Figure 2. A cold trap and detector assembly for the Fission Gas Monitoring System.

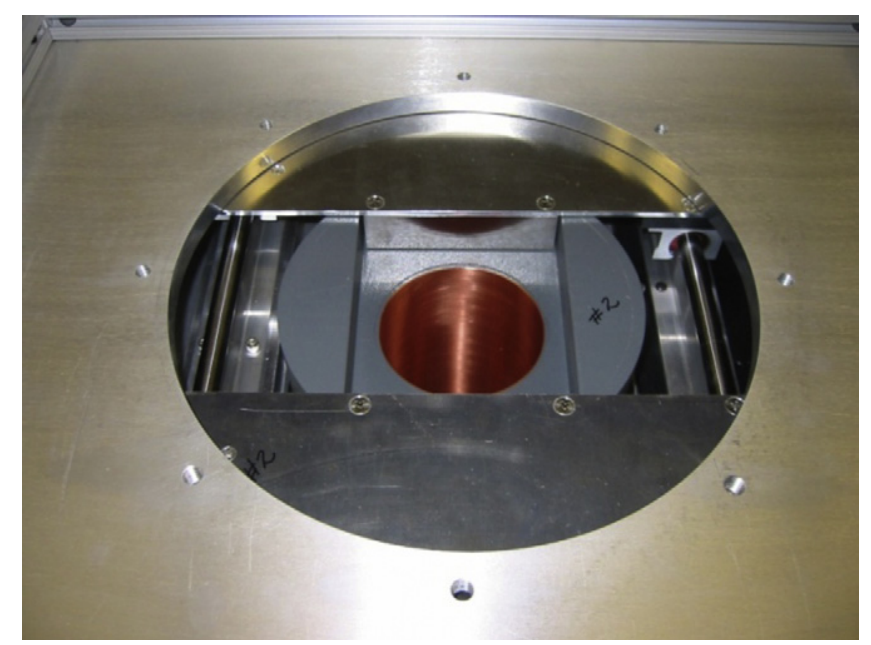

Figure 3. Automated tungsten collimator located between the cold trap assembly (above) and the high-purity germanium detector (below). The lower lead shield is shown, lined with a layer of tin and copper. 


\section{SOURCE TRANSFER}

Five certified gas standard sources (see Appendix $\mathrm{C}$ ) were purchased to obtain the system efficiency of the FGMS. Two ${ }^{133} \mathrm{Xe}$ sources $(22.6 \mu \mathrm{Ci}$ and $212.8 \mu \mathrm{Ci})$ and three ${ }^{85} \mathrm{Kr}$ sources $(0.924 \mu \mathrm{Ci}, 103.95 \mu \mathrm{Ci}$, and $390.8 \mu \mathrm{Ci})$ were used. Two helium flow rates, 0.5 liters per minute $(\mathrm{L} / \mathrm{m})$ for testing in the Fuel Conditioning Facility (FCF) and $1.0 \mathrm{~L} / \mathrm{m}$ for testing in the Hot Fuel Examination Facility (HFEF), were used. Both direct loading of the CT from the FACS and indirect loading from the other CT were tested. Table 1 shows all FGMS configurations for which efficiency measurements were made. Table 2 shows a summary of the parameters for the efficiency measurements. Figure 4 shows one of the 33-mL glass spheres containing a ${ }^{85} \mathrm{Kr}$ standard calibration source used in system efficiency measurements.

Table 2. Summary of the parameters for the efficiency measurements (see Appendix A for FGMS tabular efficiency results).

\begin{tabular}{|c|c|c|c|c|c|}
\hline Table & FGMS \# & $\begin{array}{l}\text { Helium } \\
\text { Flow Rate }\end{array}$ & Location & Source & Loading \\
\hline$A-1$ & 1 & $0.5 \mathrm{~L} / \mathrm{m}$ & FCF & ${ }^{133} \mathrm{Xe}(22.6 \mu \mathrm{Ci})$ & Direct \\
\hline A-2 & 2 & $0.5 \mathrm{~L} / \mathrm{m}$ & FCF & ${ }^{133} \mathrm{Xe}(212.8 \mu \mathrm{Ci})$ & Direct \\
\hline A-3 & 1 & $0.5 \mathrm{~L} / \mathrm{m}$ & FCF & ${ }^{85} \mathrm{Kr}(0.924 \mu \mathrm{Ci})$ & Direct \\
\hline A-4 & 2 & $0.5 \mathrm{~L} / \mathrm{m}$ & FCF & ${ }^{85} \mathrm{Kr}(103.95 \mu \mathrm{Ci})$ & Direct \\
\hline$A-5$ & 1 & $1 \mathrm{~L} / \mathrm{m}$ & HFEF & ${ }^{85} \mathrm{Kr}(390.8 \mu \mathrm{Ci})$ & Direct \\
\hline A-6 & 2 & $1 \mathrm{~L} / \mathrm{m}$ & HFEF & ${ }^{85} \mathrm{Kr}(390.8 \mu \mathrm{Ci})$ & Indirect \\
\hline$A-7$ & 1 & $1 \mathrm{~L} / \mathrm{m}$ & HFEF & ${ }^{85} \mathrm{Kr}(390.8 \mu \mathrm{Ci})$ & Indirect \\
\hline$A-8$ & 2 & $1 \mathrm{~L} / \mathrm{m}$ & Deduction & & Direct \\
\hline & & Est Ep: & & & \\
\hline
\end{tabular}

Figure 4. 33-mL glass sphere containing a ${ }^{85} \mathrm{Kr}$ standard $1.2-\mu \mathrm{Ci}$ source.

To simulate an actual FACS furnace experiment during which fuel specimens in the furnace release fission products, the furnace was first heated to $1600^{\circ} \mathrm{C}$. Then, helium was flowed from outside the hot cell through a glass sphere containing the gas source standard and then injected into the FACS furnace. The helium flowed through the tantalum flow tube and exited out the exhaust at the top of the furnace. The helium was then routed through polished stainless-steel tubing out of the hot cell and over to the FGMS. The helium flow entered the bottom of the FGMS primary CT through the charcoal and exited the top, where it was routed through the secondary CT and, eventually, to facility exhaust.

Figure 5 shows a cross-section of the CT assembly and the upper Pb shielding. A liquid nitrogen reservoir surrounds the inner vessel which contains charcoal. The charcoal is held in place by a 
retaining screen with a $50 \%$ coverage mesh. The helium sweep gas is inserted toward the bottom of the trap, below the charcoal-retaining screen. The helium flows through the mesh, through the charcoal, and exits the top of the vessel. The helium must be maintained at a constant flow so the source will freeze out in the CT in a consistent manner. Different flow rates may result in different system efficiencies. During the initial efficiency measurements in FCF, the helium flow was kept at a rate of $0.5 \mathrm{~L} / \mathrm{m}$. Later, a helium flow rate of $1.0 \mathrm{~L} / \mathrm{m}$ was established for experiments to be performed at HFEF. Therefore, all efficiency calibrations at FCF had a helium flow rate of $0.5 \mathrm{~L} / \mathrm{m}$, and all efficiency calibrations at HFEF had a helium flow rate of $1.0 \mathrm{~L} / \mathrm{m}$. Figure 6 shows the CPS measured by FGMS \#1's detector (P1) and FGMS \#2's detector (P2) during the transfer of the gas standard ${ }^{85} \mathrm{Kr}$ $(390.81 \mu \mathrm{Ci})$ source into $\mathrm{CT \# 1}$ with a helium flow rate of $1.0 \mathrm{~L} / \mathrm{m}$. Note that there was no indication any part of the ${ }^{85} \mathrm{Kr}$ source made it to the secondary trap; the entire source was captured in the primary cold trap.

For transfer of the ${ }^{85} \mathrm{Kr}(390.81 \mu \mathrm{Ci})$ source, the helium flow was started at 12:18 through the source sphere and into the furnace. Unfortunately, data collection did not begin until 12:23. In a previous test, it only took about 3 minutes for part of the source to travel through the FACS furnace to FGMS CT\#1. The entire source transfer took approximately 30 minutes. After about 90 minutes, the helium flow was stopped, and CT\#1 was sealed off. Most of the fission gas is believed to freeze to the bottom of the retaining screen, and the rest goes through the screen and freezes onto the charcoal very close to the retaining screen. The more fission gas that goes up into the charcoal, the lower the measured efficiency. Once the CT was sealed off, efficiency measurements were made for various configurations, as shown in Table 1. Multiple measurements were made for each configuration.

To study the difference between transferring a source directly from the FACS furnace to a CT and transferring from one CT to another, the ${ }^{85} \mathrm{Kr}(390.81 \mu \mathrm{Ci})$ source was transferred from CT\#1 to CT\#2. This also saved the cost of another source. Table 3 shows the timeline of the transfer. Figure 7 shows the CPS measured by P1 and P2 during the transfer into CT\#2 with a helium flow rate of $1.0 \mathrm{~L} / \mathrm{m}$. Note that the CPS measured by $\mathrm{P} 2$ is higher than that measured by $\mathrm{P} 1$; this results from different efficiencies between the two traps, possibly caused by differences in CT construction, detector efficiencies, and/or transfer methods. Figure 8 shows the CPS measured by P1 compared to the temperature of the CT during the transfer with a helium flow rate of $1.0 \mathrm{~L} / \mathrm{m}$. Note that the transfer did not start until the CT temperature reached the freezing point of krypton $\left(-157^{\circ} \mathrm{C}\right)$. The gradual decline in CPS was due to the krypton working its way through the charcoal and eventually exiting the CT. After P2 begins recording an increase in CPS, indicating the source has started to freeze out, the entire source was transferred in about 12 minutes. The sharp increase in temperature at about 10:38 occurs when monitoring of the temperature was switched from the heater tube thermocouple (TC) to the charcoal TC. The heater tube is further down in the CT and gives a more accurate reading than the charcoal TC. The switch is made because a heater is placed in the tube to increase the speed of the transfer and make sure the entire source is released.

Figure 9 shows the CPS measured by P1 and P2 during the transfer from CT\#2 back to CT\#1. Figure 10 shows the CPS measured by P2 compared to the temperature of the CT during transfer. Figure 11 shows the CPS measured by P1 during transfer from CT\#1 into a supplemental trap (U-trap) for storage. 


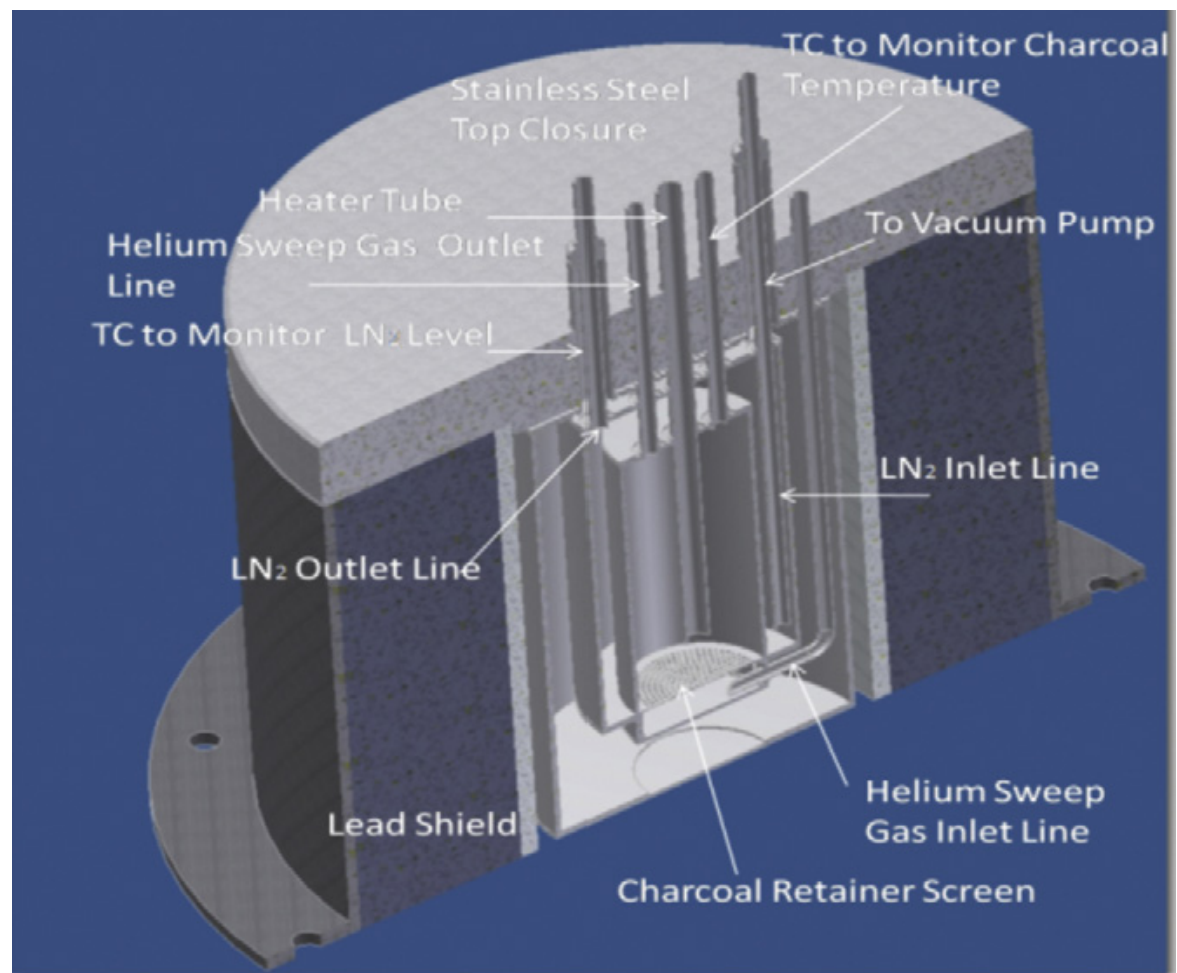

Figure 5. Cross-section of the cold trap assembly and surrounding lead shielding.

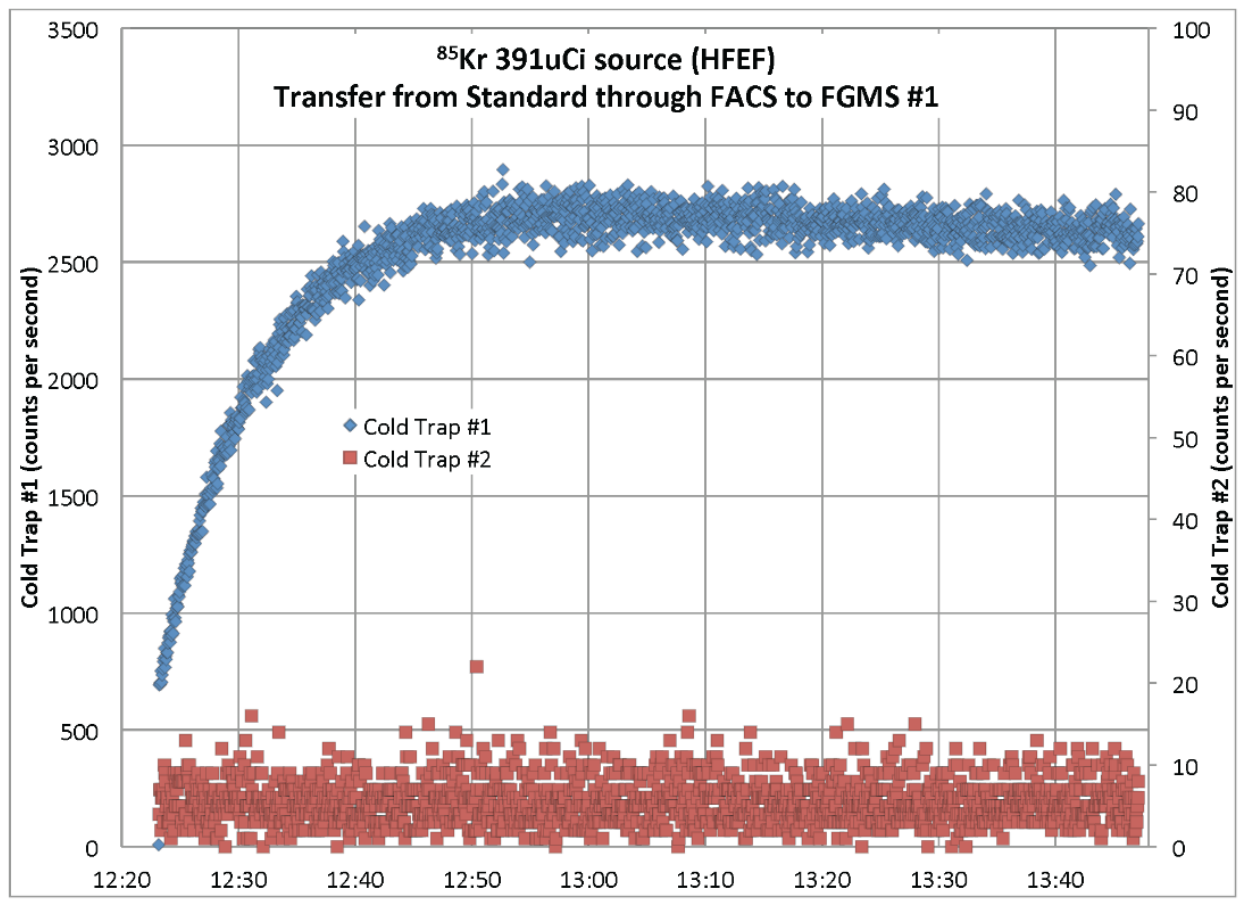

Figure 6. Standard ${ }^{85} \mathrm{Kr}$ source transfer through the FACS furnace to CT\#1 (HFEF), using a flow of 1.0 $\mathrm{L} / \mathrm{m}$ of helium. Performed on November 1, 2011. Table A-5 contains the efficiency results calculated from data collected after this transfer. 
Fission Gas Monitoring System Efficiency Calibration Summary Report

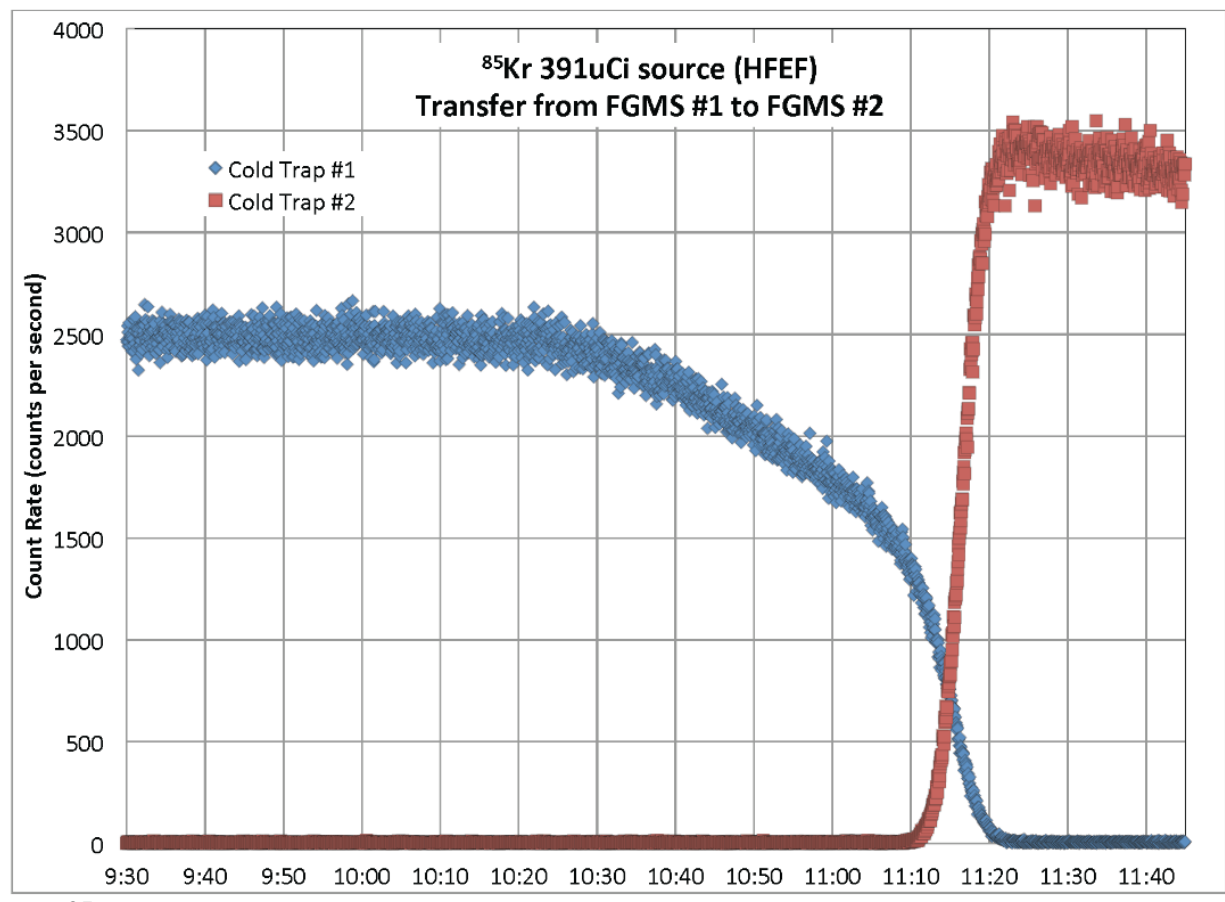

Figure 7. Standard ${ }^{85} \mathrm{Kr}$ source transfer from CT\#1 to CT\#2 (HFEF), using a flow of $1.0 \mathrm{~L} / \mathrm{m}$ of helium.

Table 3. Timeline of ${ }^{85} \mathrm{Kr}(390.81 \mu \mathrm{Ci})$ source transfer from CT\#1 to CT\#2.

\begin{tabular}{|c|c|c|}
\hline Time & $\begin{array}{l}\text { Elapsed } \\
\text { Time }\end{array}$ & $\begin{array}{c}\text { Status of }{ }^{85} \mathrm{Kr}(390.81 \mu \mathrm{Ci}) \text { Source Transfer } \\
\text { from CT\#1 to CT\#2 }\end{array}$ \\
\hline 9:24 & & Finished filling CT\#1 with liquid nitrogen and stopped liquid nitrogen autofill \\
\hline 9:32 & & Started helium flow through CT\#1 and CT\#2 \\
\hline $10: 26$ & $0: 00$ & Started to see decrease in CPS in CT\#1 \\
\hline $10: 38$ & $0: 12$ & Switched TC in CT\#1 from heater tube to charcoal \\
\hline $10: 43$ & $0: 17$ & Turned on heater in $\mathrm{CT} \# 1$ to $200^{\circ} \mathrm{F}$ \\
\hline $11: 10$ & $0: 44$ & Started to see counts in CT\#2 \\
\hline $11: 22$ & $0: 56$ & Source entirely transferred to CT\#2 \\
\hline $11: 45$ & $1: 19$ & Sealed CT\#2 and stopped data acquisition \\
\hline
\end{tabular}




\begin{tabular}{|lrr|}
\hline $\begin{array}{l}\text { TEM-10300-1, Rev. } 8 \\
11 / 20 / 2019\end{array}$ & TECHNICAL EVALUATION & TEV-1959, Rev. 0 \\
& Page 12 of 31 \\
\hline
\end{tabular}

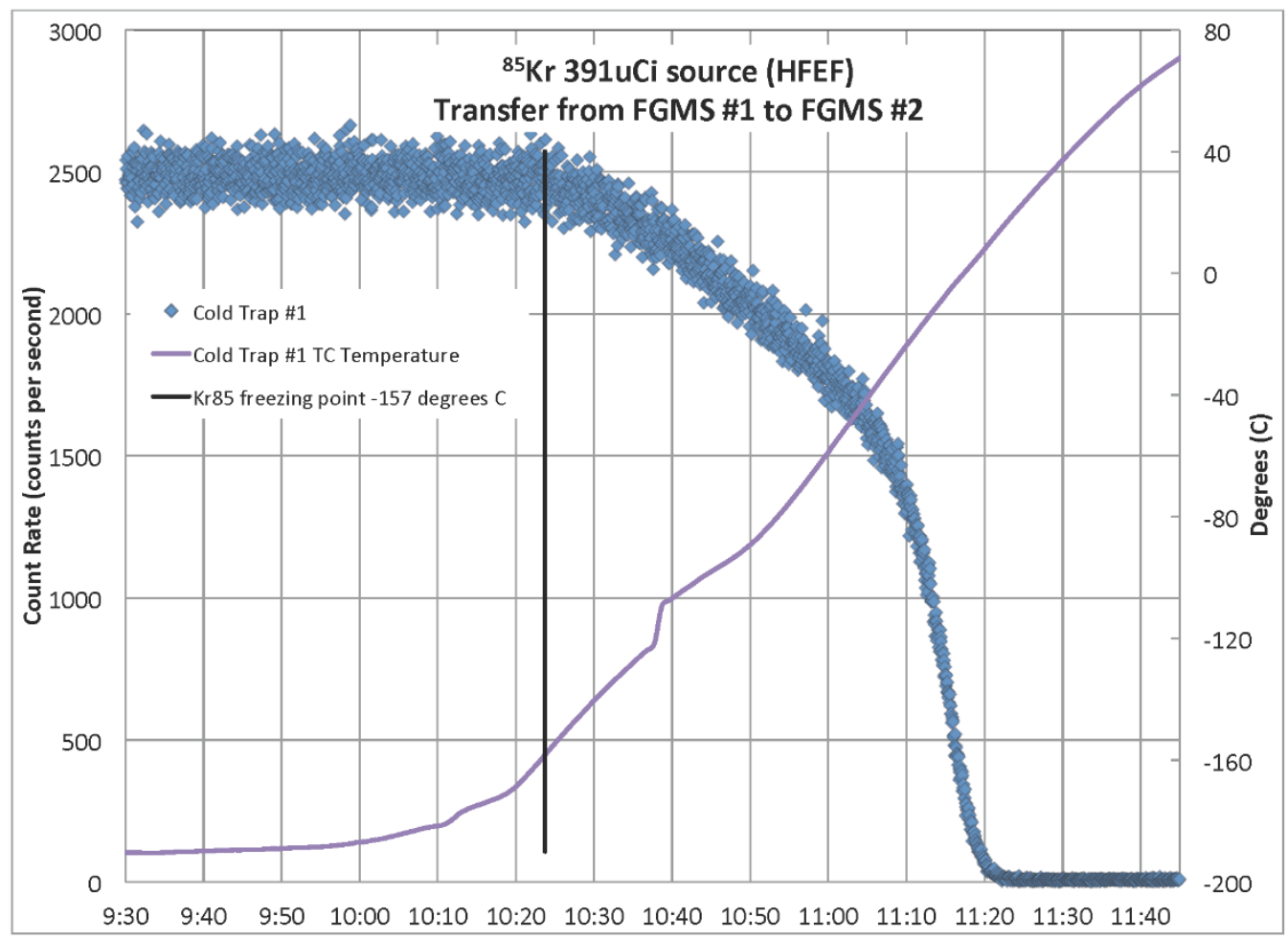

Figure 8. Transfer of the ${ }^{85} \mathrm{Kr}$ source out of CT\#1, along with the temperature of the \#1 heater tube, using a flow of $1.0 \mathrm{~L} / \mathrm{m}$ of helium.

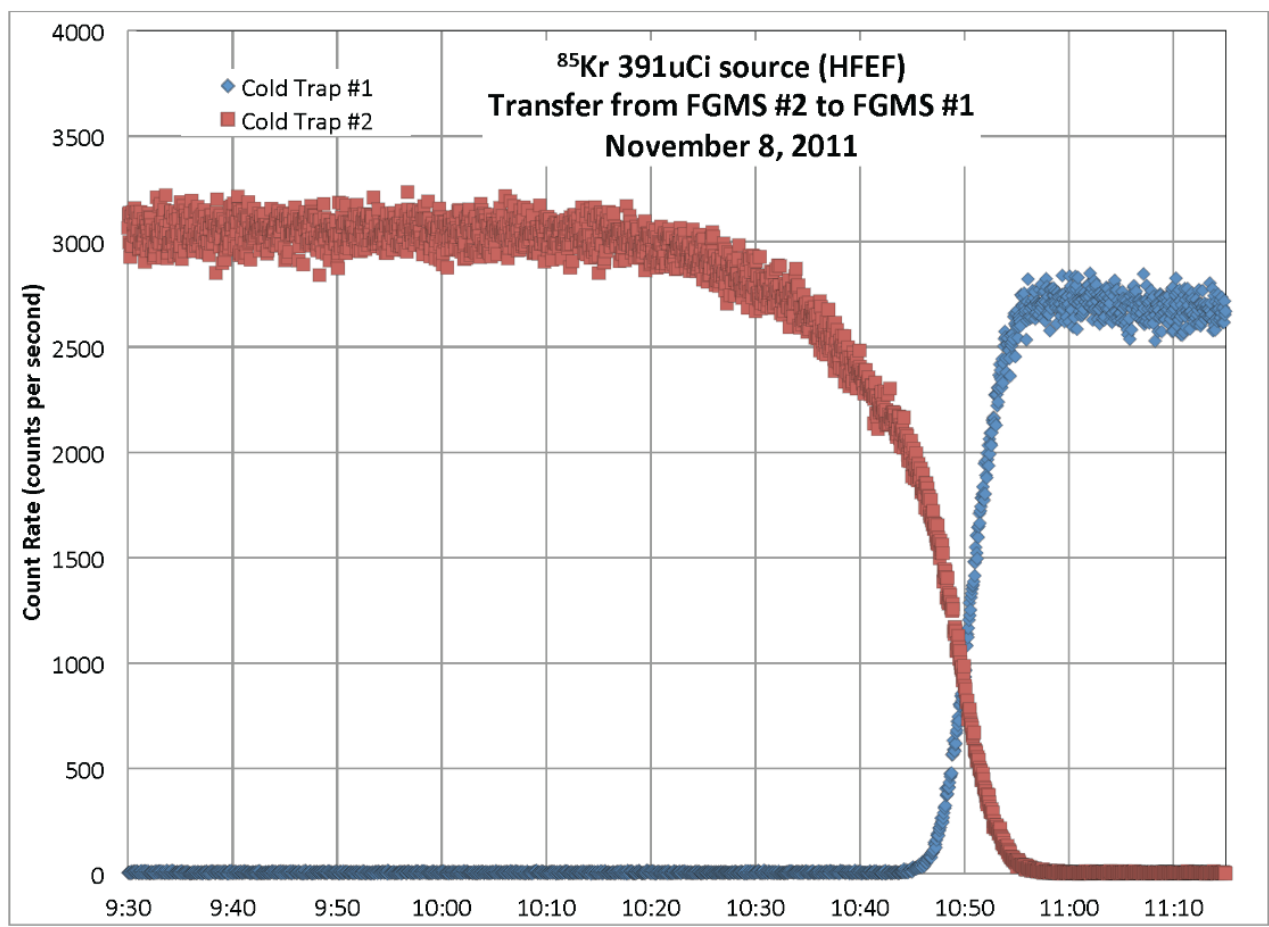

Figure 9. Standard ${ }^{85} \mathrm{Kr}$ source transfer from CT\#2 back to CT\#1 (HFEF) using a flow of $1.0 \mathrm{~L} / \mathrm{m}$ of helium. 


\begin{tabular}{|lrr|}
\hline $\begin{array}{l}\text { TEM-10300-1, Rev. } 8 \\
11 / 20 / 2019\end{array}$ & TECHNICAL EVALUATION & TEV-1959, Rev. 0 \\
& Page 13 of 31 \\
\hline
\end{tabular}

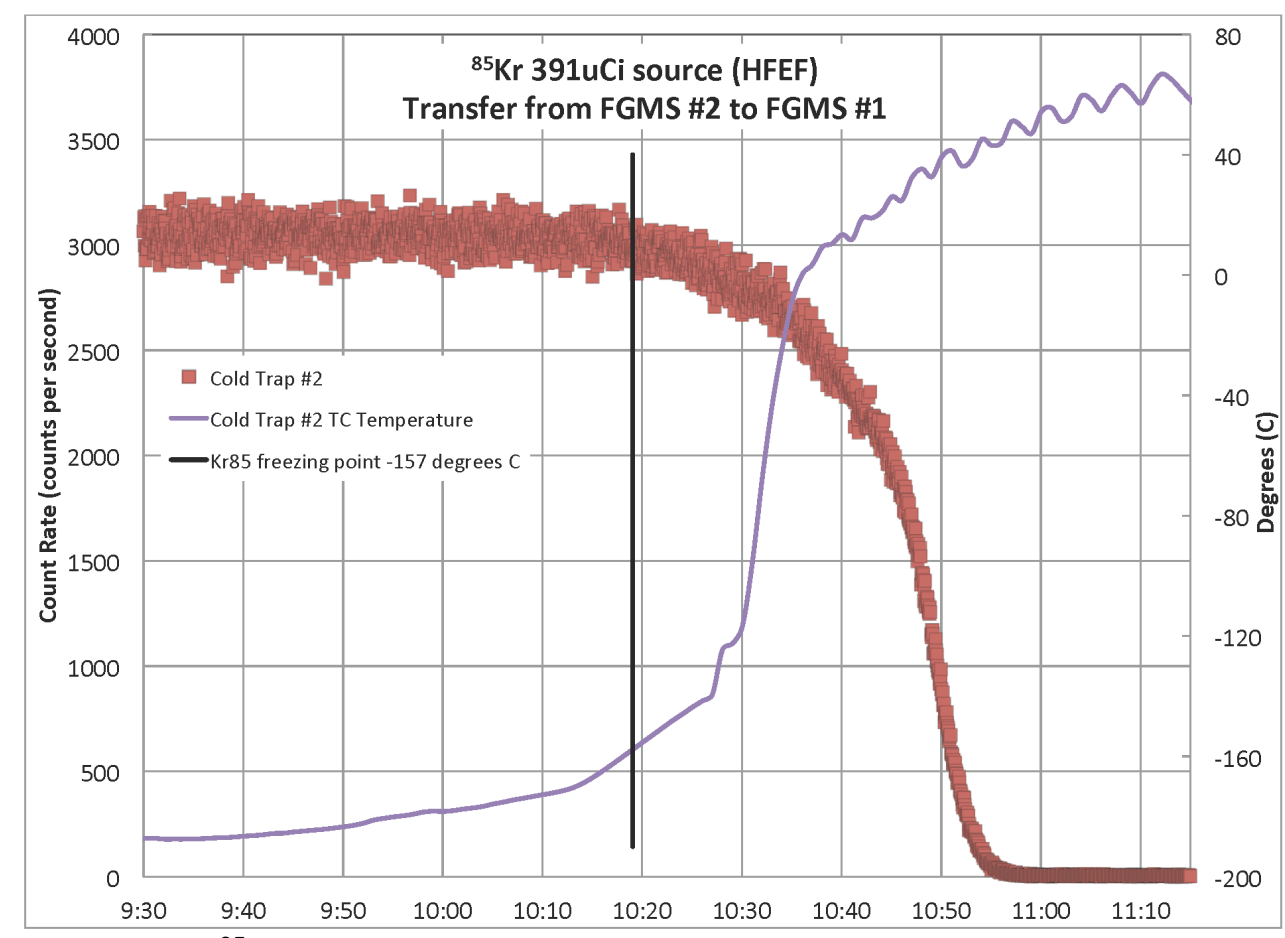

Figure 10. Transfer of the ${ }^{85} \mathrm{Kr}$ source out of CT\#2, along with the temperature of the \#2 heater tube.

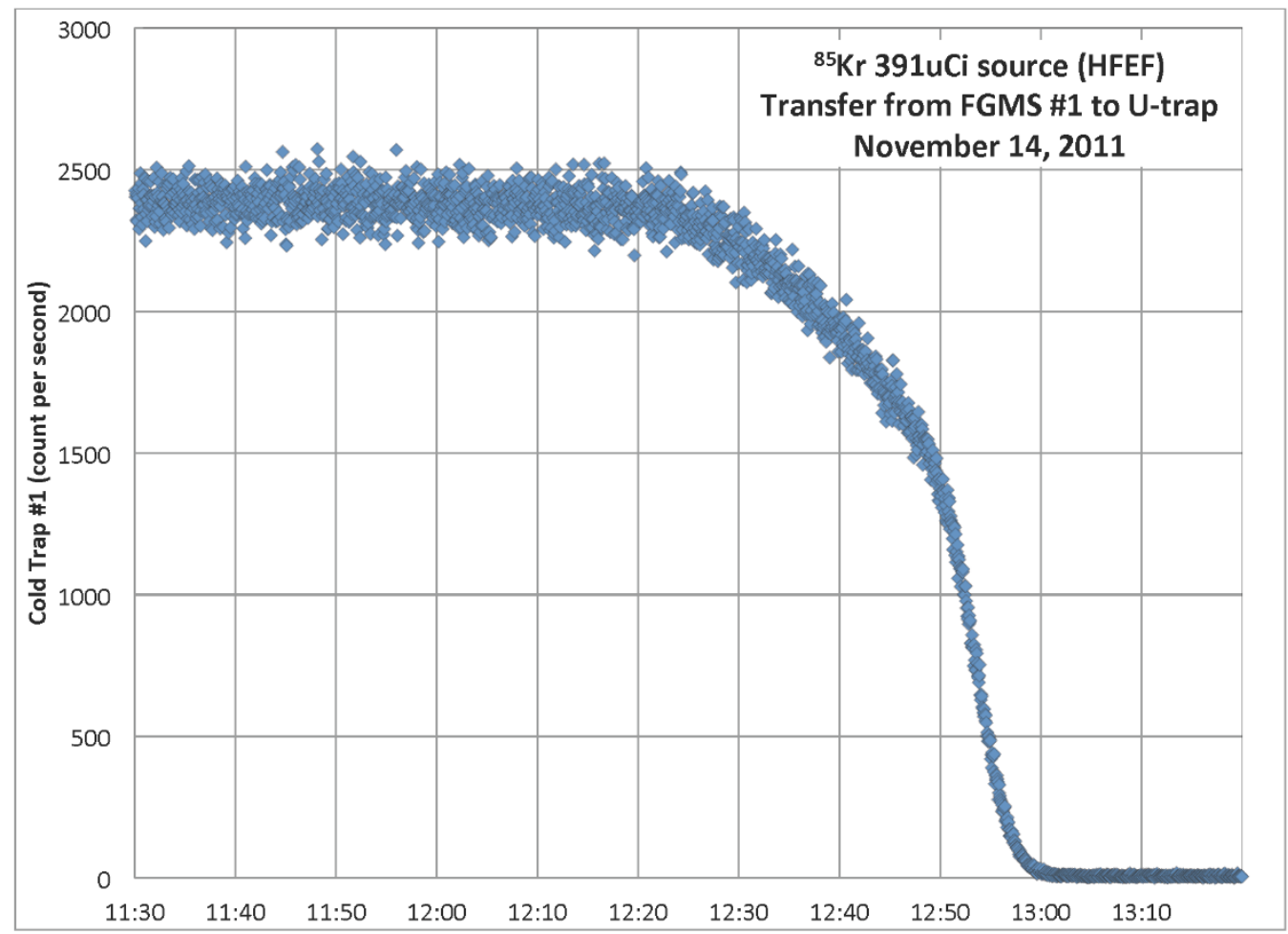

Figure 11. Standard ${ }^{85} \mathrm{Kr}$ source transfer from CT\#1 to a U-trap (HFEF), using a flow of $1.0 \mathrm{~L} / \mathrm{m}$ of helium. 


\section{EFFICIENCY MEASUREMENT AND COMPARISON}

Ideally, to get the most accurate system efficiency, one would mimic as closely as possible the parameters to be used in the actual experiment. In addition, it is necessary to use a certified gas standard source with the same isotopic makeup as the isotopes of interest. In this case, ${ }^{133} \mathrm{Xe}$ and ${ }^{85} \mathrm{Kr}$ are the isotopes of interest, emitting gamma rays of $81 \mathrm{keV}$ and $514 \mathrm{keV}$, respectively.

The most accurate way to mimic failing of fuel in the FACS furnace is to inject the certified source into the FACS furnace at temperature and directly load the CT. If the primary CT fails, it would be necessary to transfer the contents to the secondary trap. Therefore, transferring the certified source from CT\#1 to CT\#2 was also performed to record the efficiency. This was done to study whether there is any difference in the efficiencies between loading the CT directly from the FACS and from the other CT.

Once measurements of a source are complete, the peak area of the gamma ray of interest is determined. But knowing the live time, real time, peak area, emission probability, and half-lives, and by using the formulas in Appendix B, the efficiency can be calculated.

Figure 12 and Figure 13 show a comparison of the efficiency measurements of the two flow rates for FGMS \#1 and \#2, respectively. As expected, the 1.0-L/m efficiency measurements were lower than the $0.5-\mathrm{L} / \mathrm{m}$ rate. The higher helium flow rate allows less time for fission gas to freeze out on the retaining screen before going into the charcoal. As can be seen, efficiency measurements at a detector-CT distance of $0 \mathrm{~cm}$ show the greatest separation. This indicates an extended source (i.e., the more one moves away from an extended source, the less the source geometry affects the efficiency measurements, and the more it appears to be a point source). That being said, one has to consider whether the large difference in the two source activities affected the results. To address this, a comparison is made between the ratios of the efficiencies of P2 $5.740 \mathrm{E}-3(103.95 \mu \mathrm{Ci}, 0.5 \mathrm{~L} / \mathrm{m})$ and 5.145E-3 $(390.81 \mu \mathrm{Ci}, 1 \mathrm{~L} / \mathrm{m}), 1.12$, and P1 4.686E-3 $(0.924 \mu \mathrm{Ci}, 0.5 \mathrm{~L} / \mathrm{m})$ and $4.050 \mathrm{E}-3(390.81 \mu \mathrm{Ci}$, $1 \mathrm{~L} / \mathrm{m}), 1.16$. These two ratios $(1.12$ and 1.16$)$ are very similar and suggest that using different amounts of Kr85 does not affect the efficiencies.

Figure 14 shows a comparison between direct loading of CT\#1 and indirect loading of CT\#1 from CT\#2. Source transfer from CT\#2 to CT\#1 results in a slightly higher efficiency than when the source is loaded directly from the FACS furnace.

A direct loading of CT\#2 for ${ }^{85} \mathrm{Kr}$ with a helium flow rate of $1 \mathrm{~L} / \mathrm{m}$ was never measured. Because of this, the efficiency was estimated using the indirect loading of CT\#2 and a gain factor obtained from the ratio of indirect versus direct loading of CT\#1. FGMS \#2 is a backup system not intended to be the primary trap directly loaded from the FACS furnace.

Efficiency measurements using ${ }^{133} \mathrm{Xe}$ were not taken with a helium flow rate of $1 \mathrm{~L} / \mathrm{m} .{ }^{133} \mathrm{Xe}(81 \mathrm{keV})$ should not be present unless the fuel is re-irradiated. If this is going to occur, an efficiency measurement must be made.

Data for some of the collimator shutter widths are missing due to liquid nitrogen filling problems, which caused the cold traps to warm up and make the data unreliable. This occurred after the important detector-CT distances and collimator widths were finished. The likelihood of needing the missing data is extremely low, and the expense of obtaining the measurements is high. Therefore, it was decided not to make those measurements. 
Fission Gas Monitoring System Efficiency Calibration Summary Report

\section{Fission Gas Monitoring System Efficiency Calibration Summary Report}

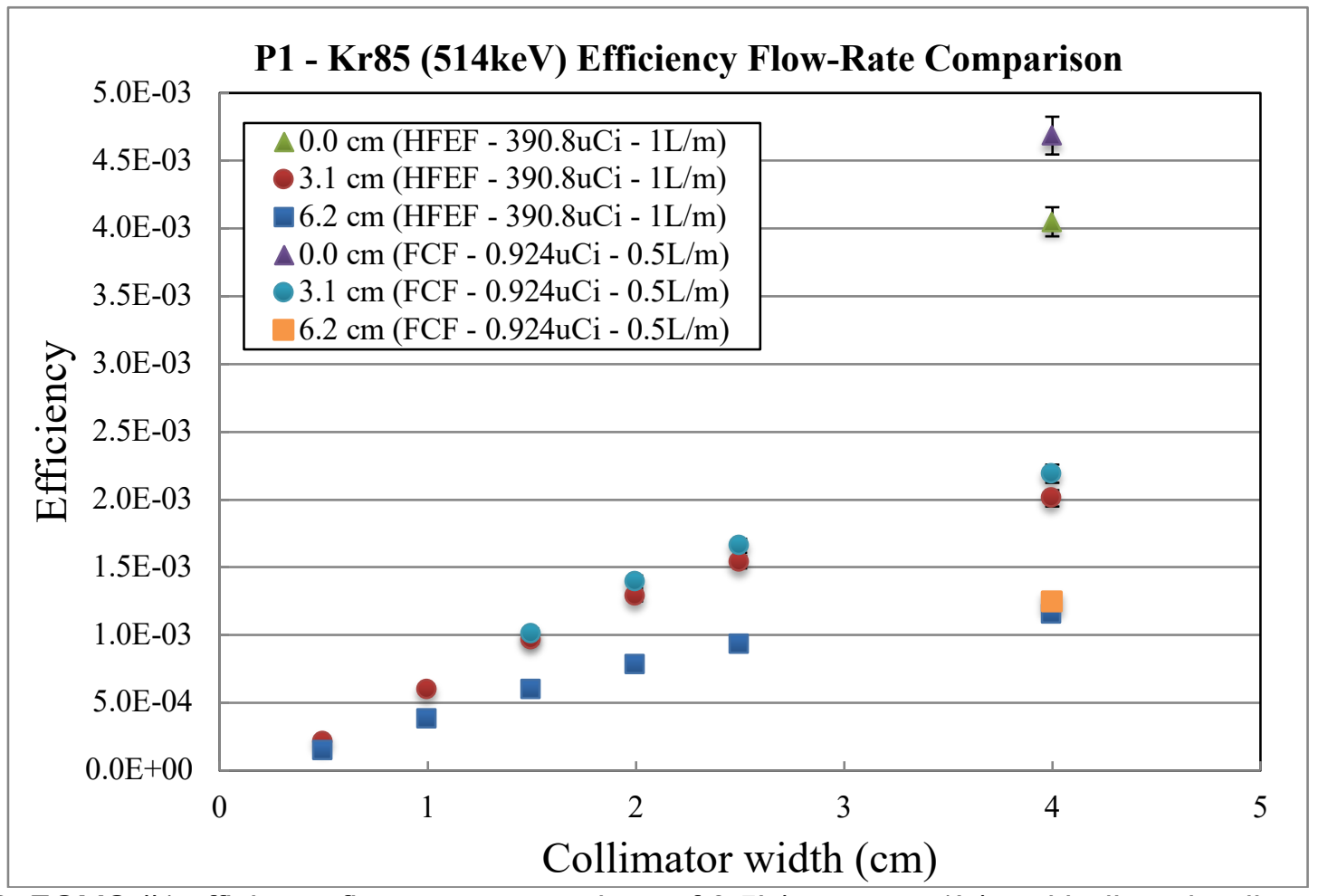

Figure 12. FGMS \#1 efficiency flow-rate comparison of $0.5 \mathrm{~L} / \mathrm{m}$ versus $1 \mathrm{~L} / \mathrm{m}$ with direct loading of the cold traps. Data from Table A-3 and Table A-5 were used to generate this plot. For display purposes, the collimator shutter width of $11 \mathrm{~cm}$ is shown as $4 \mathrm{~cm}$ on the plot. 
Fission Gas Monitoring System Efficiency Calibration Summary Report

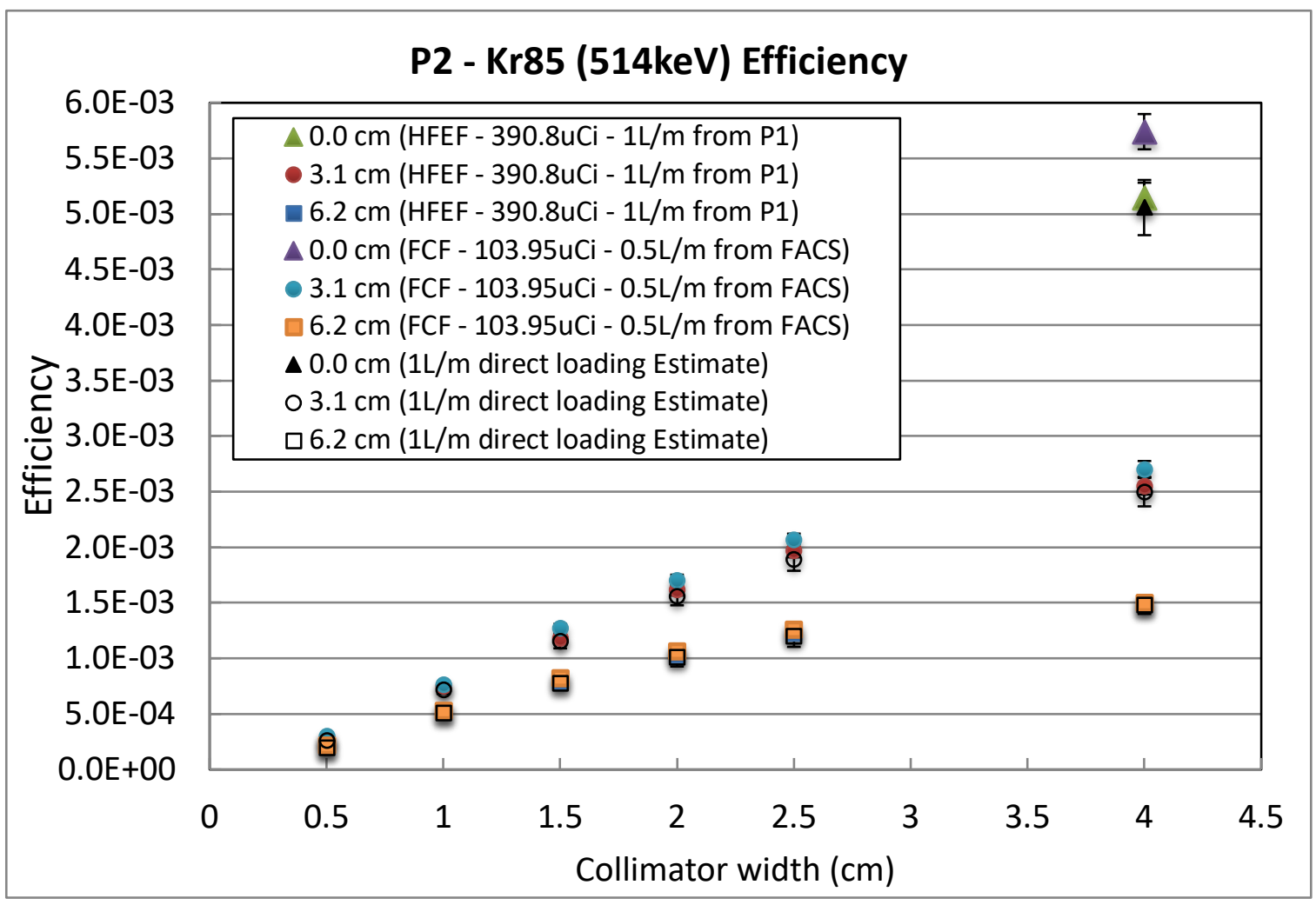

Figure 13. FGMS \#2 efficiency flow-rate comparison and estimations. Data from Table A-4, Table A-6, and Table A-8 were used to generate this plot. For display purposes, the collimator shutter width of 11 $\mathrm{cm}$ is shown as $4 \mathrm{~cm}$ on the plot. 


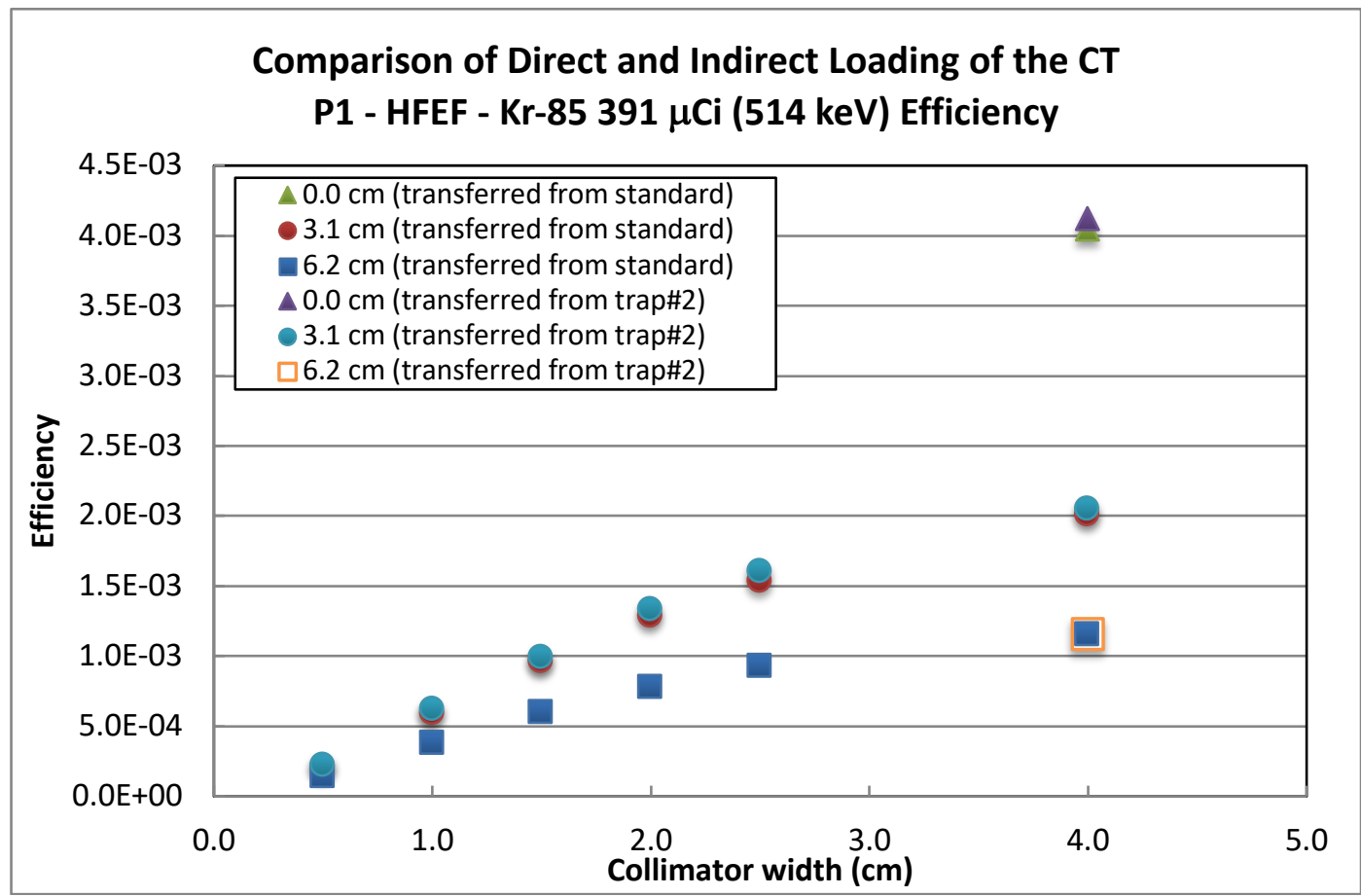

Figure 14. FGMS \#1 comparison of direct loading and transfer from the other cold trap $(1.0 \mathrm{~L} / \mathrm{m})$. Data from Table A-5 and Table A-7 were used to generate this plot. For display purposes, the collimator shutter width of $11 \mathrm{~cm}$ is shown as $4 \mathrm{~cm}$ on the plot.

\section{SUMMARY}

The FGMS was calibrated with five certified standards, ranging from 0.924 to $390.8 \mu \mathrm{Ci}$. This range of activity simulated prospective AGR-1 fuel failure within the FACS furnace, ranging from a simulated inventory of one failed particle to many failed particles. HPGe detector responses were obtained at three different detector-to-trap differences (i.e., height), with the corresponding collimation shutter width ranging from 0.5 to $11.0 \mathrm{~cm}$. An efficiency calibration curve was generated for each configuration.

These measurements enabled the FGMS team to quantify the activity of the fission gas captured within the FGMS CTs.

Efficiency measurements were acquired from December 2009 to November 2011 and performed at FCF (mockup shop) and HFEF. The FGMS now permanently resides at HFEF. Efficiency measurements were performed during this extended time span because of certified standard availability, budget constraints, facility shutdowns, and other parameters outside the FGMS support team's control.

Measurements provided in this report satisfy the requirements for the AGR-1 fuel post-irradiation examination experiment series. It is recommended that periodic efficiency measurements are performed to ensure that increased usage of the cold traps does not affect their efficiencies. 


\section{ACRONYMS}

AGR Advanced Gas Reactor

CT cold trap

CPS counts per second

FACS Fuel Accident Condition Simulator Furnace

FCF Fuel Conditioning Facility (located in the Materials Fuels Complex at the Idaho National Laboratory)

FGMS Fission Gas Monitoring System

HFEF Hot Fuel Examination Facility (located in the Materials Fuels Complex at the Idaho National Laboratory)

HPGe high-purity germanium

Kr krypton

$\mathrm{L} / \mathrm{m} \quad$ liters per minute

$\mathrm{Pb} \quad$ lead

P1 HPGe detector used in FGMS \#1 to monitor CT\#1

P2 HPGe detector used in FGMS \#2 to monitor CT\#2

TC thermocouple

Xe xenon

\section{REFERENCES}

1. Debertin, Klaus, and Richard Helmer. 1988. "Efficiency calibration and emission-rate determinations." In Gamma- and X-ray Spectrometry with Semiconductor Detectors. 205-289. Amsterdam: Elsevier Science B.V.

2. AGR-1 PIE FGMS \#1, LAB-1194, Idaho National Laboratory.

3. AGR PIE FGMS \#2, LAB-1602, Idaho National Laboratory. 


\section{Appendix A}

\section{FGMS Tabular Efficiency Results}

\section{${ }^{133} \mathrm{Xe}$ (81.0 keV, 5.243 Days Half-Life) Efficiency: FCF Mockup, 0.5 L/m Helium Flow}

Table A-1. FGMS \#1 efficiency measurements using ${ }^{133} \mathrm{Xe}(22.57 \mu \mathrm{Ci}, 80860-370)$ source transferred using a helium flow of $0.5 \mathrm{~L} / \mathrm{m}$ (FCF) directly to CT\#1. A systematic uncertainty of $2 \%$ was added to the statistical uncertainty.

\begin{tabular}{ccccccc} 
Distance & Collimator $(\mathrm{cm})$ & Efficiency & Uncertainty & Measurements & $\begin{array}{c}\text { 1st Data } \\
\text { Taken }\end{array}$ & $\begin{array}{c}\text { Last Data } \\
\text { Taken }\end{array}$ \\
\hline 0 & 11.0 & $3.258 \mathrm{E}-03$ & $2.0 \%$ & 5 & $12 / 01 / 09$ & $12 / 01 / 09$ \\
3.1 & 11.0 & $1.617 \mathrm{E}-03$ & $2.0 \%$ & 5 & $12 / 01 / 09$ & $12 / 01 / 09$ \\
3.1 & 2.5 & $1.151 \mathrm{E}-03$ & $2.0 \%$ & 5 & $12 / 01 / 09$ & $12 / 01 / 09$ \\
3.1 & 2.0 & $9.131 \mathrm{E}-04$ & $2.0 \%$ & 5 & $12 / 01 / 09$ & $12 / 01 / 09$ \\
3.1 & 1.5 & $6.383 \mathrm{E}-04$ & $2.0 \%$ & 5 & $12 / 01 / 09$ & $12 / 01 / 09$ \\
3.1 & 1.0 & $3.459 \mathrm{E}-04$ & $2.0 \%$ & 5 & $12 / 01 / 09$ & $12 / 01 / 09$ \\
3.1 & 0.5 & $9.383 \mathrm{E}-05$ & $2.0 \%$ & 5 & $12 / 01 / 09$ & $12 / 01 / 09$ \\
6.2 & 11.0 & $9.058 \mathrm{E}-04$ & $2.0 \%$ & 5 & $11 / 30 / 09$ & $11 / 30 / 09$ \\
6.2 & 2.5 & $6.786 \mathrm{E}-04$ & $2.0 \%$ & 5 & $12 / 01 / 09$ & $12 / 01 / 09$ \\
6.2 & 2.0 & $5.259 \mathrm{E}-04$ & $2.0 \%$ & 5 & $12 / 04 / 09$ & $12 / 05 / 09$ \\
6.2 & 1.5 & $3.807 \mathrm{E}-04$ & $2.0 \%$ & 5 & $12 / 05 / 09$ & $12 / 06 / 09$ \\
6.2 & 1.0 & $2.220 \mathrm{E}-04$ & $2.0 \%$ & 5 & $12 / 03 / 09$ & $12 / 03 / 09$ \\
6.2 & 0.5 & $6.686 \mathrm{E}-05$ & $2.0 \%$ & 5 & $12 / 03 / 09$ & $12 / 03 / 09$ \\
\hline
\end{tabular}

Table A-2. FGMS \#2 efficiency measurements using ${ }^{133} \mathrm{Xe}(212.76 \mu \mathrm{Ci}, 80861-370)$ source transferred using a helium flow of $0.5 \mathrm{~L} / \mathrm{m}$ (FCF) directly to CT\#2. A systematic uncertainty of $2 \%$ was added to the statistical uncertainty.

\begin{tabular}{ccccccc}
\hline Distance & Collimator $(\mathrm{cm})$ & Efficiency & Uncertainty & Measurements & $\begin{array}{c}\text { 1st Data } \\
\text { Taken }\end{array}$ & $\begin{array}{c}\text { Last Data } \\
\text { Taken }\end{array}$ \\
\hline 0 & 11.0 & $3.734 \mathrm{E}-03$ & $2.0 \%$ & 15 & $12 / 14 / 09$ & $12 / 16 / 09$ \\
3.1 & 11.0 & $1.795 \mathrm{E}-03$ & $2.0 \%$ & 15 & $12 / 14 / 09$ & $12 / 16 / 09$ \\
3.1 & 2.5 & $1.236 \mathrm{E}-03$ & $2.0 \%$ & 5 & $12 / 14 / 09$ & $12 / 14 / 09$ \\
3.1 & 2.0 & $9.945 \mathrm{E}-04$ & $2.0 \%$ & 5 & $12 / 15 / 09$ & $12 / 15 / 09$ \\
3.1 & 1.5 & $7.482 \mathrm{E}-04$ & $2.0 \%$ & 5 & $12 / 15 / 09$ & $12 / 15 / 09$ \\
3.1 & 1.0 & $4.284 \mathrm{E}-04$ & $2.0 \%$ & 5 & $12 / 15 / 09$ & $12 / 15 / 09$ \\
3.1 & 0.5 & $1.467 \mathrm{E}-04$ & $2.0 \%$ & 5 & $12 / 15 / 09$ & $12 / 15 / 09$ \\
6.2 & 11.0 & $1.018 \mathrm{E}-03$ & $2.0 \%$ & 15 & $12 / 14 / 09$ & $12 / 16 / 09$ \\
6.2 & 2.5 & $7.719 \mathrm{E}-04$ & $2.0 \%$ & 5 & $12 / 14 / 09$ & $12 / 14 / 09$ \\
6.2 & 2.0 & $6.591 \mathrm{E}-04$ & $2.0 \%$ & 5 & $12 / 15 / 09$ & $12 / 15 / 09$ \\
6.2 & 1.5 & $5.043 \mathrm{E}-04$ & $2.0 \%$ & 5 & $12 / 15 / 09$ & $12 / 15 / 09$ \\
6.2 & 1.0 & $2.944 \mathrm{E}-04$ & $2.0 \%$ & 5 & $12 / 15 / 09$ & $12 / 16 / 09$ \\
6.2 & 0.5 & $8.172 \mathrm{E}-05$ & $2.0 \%$ & 5 & $12 / 14 / 09$ & $12 / 14 / 09$ \\
\hline
\end{tabular}


Fission Gas Monitoring System Efficiency Calibration Summary Report

\section{${ }^{85} \mathrm{Kr}(514.0 \mathrm{keV}, 10.756$ Years Half-Life [YHL]) Efficiency Fuel Conditioning Facility}

Table A-3. FGMS \#1 efficiency measurements using ${ }^{85} \mathrm{Kr}(0.924 \mu \mathrm{Ci}, 80511-370)$ source transferred using a helium flow of $0.5 \mathrm{~L} / \mathrm{m}$ (FCF) directly to CT\#1. A systematic uncertainty of $2 \%$ was added to the statistical uncertainty.

\begin{tabular}{ccccccc}
\hline Distance & $\begin{array}{c}\text { Collimator } \\
(\mathrm{cm})\end{array}$ & Efficiency & Uncertainty & Measurements & $\begin{array}{c}\text { 1st Data } \\
\text { Taken }\end{array}$ & $\begin{array}{c}\text { Last Data } \\
\text { Taken }\end{array}$ \\
\hline 0 & 11.0 & $4.686 \mathrm{E}-03$ & $3.0 \%$ & 5 & $04 / 15 / 10$ & $04 / 16 / 10$ \\
3.1 & 11.0 & $2.191 \mathrm{E}-03$ & $3.1 \%$ & 5 & $04 / 16 / 10$ & $04 / 18 / 10$ \\
3.1 & 2.5 & $1.659 \mathrm{E}-03$ & $3.1 \%$ & 5 & $05 / 04 / 10$ & $05 / 08 / 10$ \\
3.1 & 2.0 & $1.393 \mathrm{E}-03$ & $3.4 \%$ & 4 & $04 / 28 / 10$ & $04 / 29 / 10$ \\
3.1 & 1.5 & $1.012 \mathrm{E}-03$ & $3.6 \%$ & 4 & $04 / 30 / 10$ & $05 / 03 / 10$ \\
6.2 & 11.0 & $1.245 \mathrm{E}-03$ & $3.4 \%$ & 3 & $04 / 19 / 10$ & $04 / 20 / 10$ \\
\hline
\end{tabular}

Table A-4. FGMS \#2 efficiency measurements using ${ }^{85} \mathrm{Kr}(103.95 \mu \mathrm{Ci}, 80513-370)$ source transferred using a helium flow of $0.5 \mathrm{~L} / \mathrm{m}$ (FCF) directly to CT\#2. A systematic uncertainty of $2 \%$ was added to the statistical uncertainty.

\begin{tabular}{ccccccc}
\hline Distance & $\begin{array}{c}\text { Collimator } \\
(\mathrm{cm})\end{array}$ & Efficiency & Uncertainty & Measurements & $\begin{array}{c}\text { 1st Data } \\
\text { Taken }\end{array}$ & $\begin{array}{c}\text { Last Data } \\
\text { Taken }\end{array}$ \\
\hline 0 & 11.0 & $5.740 \mathrm{E}-03$ & $2.8 \%$ & 6 & $06 / 15 / 10$ & $06 / 15 / 10$ \\
3.1 & 11.0 & $2.700 \mathrm{E}-03$ & $2.8 \%$ & 5 & $06 / 16 / 10$ & $06 / 16 / 10$ \\
3.1 & 2.5 & $2.064 \mathrm{E}-03$ & $2.9 \%$ & 5 & $06 / 16 / 10$ & $06 / 16 / 10$ \\
3.1 & 2.0 & $1.704 \mathrm{E}-03$ & $2.9 \%$ & 5 & $06 / 16 / 10$ & $06 / 16 / 10$ \\
3.1 & 1.5 & $1.273 \mathrm{E}-03$ & $2.9 \%$ & 5 & $06 / 16 / 10$ & $06 / 16 / 10$ \\
3.1 & 1.0 & $7.646 \mathrm{E}-04$ & $2.7 \%$ & 10 & $06 / 21 / 10$ & $06 / 24 / 10$ \\
3.1 & 0.5 & $2.981 \mathrm{E}-04$ & $2.9 \%$ & 5 & $06 / 16 / 10$ & $06 / 17 / 10$ \\
6.2 & 11.0 & $1.502 \mathrm{E}-03$ & $2.6 \%$ & 9 & $06 / 21 / 10$ & $06 / 24 / 10$ \\
6.2 & 2.5 & $1.258 \mathrm{E}-03$ & $2.8 \%$ & 5 & $06 / 22 / 10$ & $06 / 22 / 10$ \\
6.2 & 2.0 & $1.060 \mathrm{E}-03$ & $2.7 \%$ & 7 & $06 / 22 / 10$ & $06 / 24 / 10$ \\
6.2 & 1.5 & $8.210 \mathrm{E}-04$ & $2.8 \%$ & 5 & $06 / 22 / 10$ & $06 / 23 / 10$ \\
\hline
\end{tabular}


Fission Gas Monitoring System Efficiency Calibration Summary Report

$\begin{array}{lllllll}6.2 & 1.0 & 5.288 \mathrm{E}-04 & 2.8 \% & 5 & 06 / 21 / 10 & 06 / 22 / 10 \\ 6.2 & 0.5 & 2.130 \mathrm{E}-04 & 2.8 \% & 6 & 06 / 17 / 10 & 06 / 18 / 10\end{array}$

\section{FGMS Efficiency Results (HFEF, 1.0 L/m Helium Flow)}

\section{${ }^{85} \mathrm{Kr}$ (514.0 keV, 10.756 Years Half-Life [YHL]) Efficiency}

Table A-5. FGMS \#1 efficiency measurements using ${ }^{85} \mathrm{Kr}$ (390.81 $\left.\mu \mathrm{Ci}, 80514-370\right)$ source through the FACS furnace at $1600^{\circ} \mathrm{C}$ transferred using a helium flow of $1.0 \mathrm{~L} / \mathrm{m}$ (HFEF) directly to CT\#1. A systematic uncertainty of $2 \%$ was added to the statistical uncertainty.

\begin{tabular}{|c|c|c|c|c|c|c|}
\hline Distance & $\begin{array}{l}\text { Collimator } \\
(\mathrm{cm})\end{array}$ & Efficiency & Uncertainty & Measurements & $\begin{array}{c}\text { 1st Data } \\
\text { Taken }\end{array}$ & $\begin{array}{c}\text { Last Data } \\
\text { Taken }\end{array}$ \\
\hline 0 & 11.0 & 4.050E-03 & $2.7 \%$ & 9 & $11 / 01 / 11$ & $11 / 03 / 11$ \\
\hline 3.1 & 11.0 & 2.009E-03 & $3.0 \%$ & 3 & $11 / 01 / 11$ & $11 / 01 / 11$ \\
\hline 3.1 & 2.5 & $1.539 \mathrm{E}-03$ & $3.0 \%$ & 3 & $11 / 01 / 11$ & $11 / 01 / 11$ \\
\hline 3.1 & 2.0 & $1.288 \mathrm{E}-03$ & $3.0 \%$ & 3 & $11 / 02 / 11$ & $11 / 02 / 11$ \\
\hline 3.1 & 1.5 & 9.673E-04 & $3.1 \%$ & 3 & $11 / 02 / 11$ & $11 / 02 / 11$ \\
\hline 3.1 & 1.0 & 5.961E-04 & $3.1 \%$ & 3 & $11 / 03 / 11$ & $11 / 03 / 11$ \\
\hline 3.1 & 0.5 & 2.113E-04 & $3.0 \%$ & 3 & $11 / 02 / 11$ & $11 / 02 / 11$ \\
\hline 6.2 & 11.0 & 1.156E-03 & $3.1 \%$ & 3 & $11 / 02 / 11$ & $11 / 02 / 11$ \\
\hline 6.2 & 2.5 & $9.311 \mathrm{E}-04$ & $3.0 \%$ & 3 & $11 / 02 / 11$ & $11 / 02 / 11$ \\
\hline 6.2 & 2.0 & 7.818E-04 & $3.1 \%$ & 3 & $11 / 02 / 11$ & $11 / 02 / 11$ \\
\hline 6.2 & 1.5 & 5.977E-04 & $3.1 \%$ & 3 & $11 / 03 / 11$ & $11 / 03 / 11$ \\
\hline 6.2 & 1.0 & 3.783E-04 & $3.1 \%$ & 3 & $11 / 02 / 11$ & $11 / 02 / 11$ \\
\hline 6.2 & 0.5 & $1.459 \mathrm{E}-04$ & $3.0 \%$ & 3 & $11 / 01 / 11$ & $11 / 01 / 11$ \\
\hline
\end{tabular}

Table A-6. FGMS \#2 efficiency measurements using ${ }^{85} \mathrm{Kr}(390.81 \mu \mathrm{Ci}$, 80514-370) source transferred from the FGMS CT\#1 (indirect) using a helium flow of $1.0 \mathrm{~L} / \mathrm{m}$ (HFEF). A systematic uncertainty of $2 \%$ was added to the statistical uncertainty.

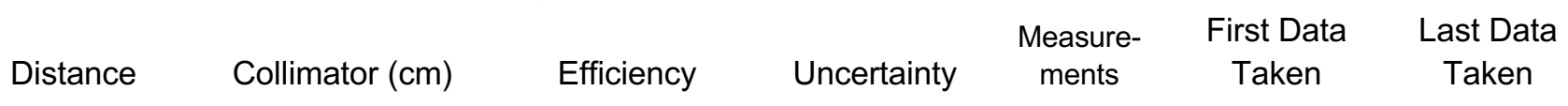


Fission Gas Monitoring System Efficiency Calibration Summary Report

$\begin{array}{lllllll}0 & 11.0 & 5.145 \mathrm{E}-03 & 2.6 \% & 9 & 11 / 07 / 11 & 11 / 08 / 11 \\ 3.1 & 11.0 & 2.551 \mathrm{E}-03 & 3.0 \% & 3 & 11 / 07 / 11 & 11 / 07 / 11 \\ 3.1 & 2.5 & 1.970 \mathrm{E}-03 & 3.1 \% & 3 & 11 / 07 / 11 & 11 / 07 / 11 \\ 3.1 & 2.0 & 1.616 \mathrm{E}-03 & 3.1 \% & 3 & 11 / 07 / 11 & 11 / 07 / 11 \\ 3.1 & 1.5 & 1.182 \mathrm{E}-03 & 3.1 \% & 3 & 11 / 08 / 11 & 11 / 08 / 11 \\ 3.1 & 1.0 & 7.527 \mathrm{E}-04 & 3.1 \% & 3 & 11 / 07 / 11 & 11 / 07 / 11 \\ 3.1 & 0.5 & 2.773 \mathrm{E}-04 & 3.1 \% & 3 & 11 / 08 / 11 & 11 / 08 / 11 \\ 6.2 & 11.0 & 1.484 \mathrm{E}-03 & 3.1 \% & 3 & 11 / 07 / 11 & 11 / 07 / 11 \\ 6.2 & 2.5 & 1.224 \mathrm{E}-03 & 3.3 \% & 2 & 11 / 07 / 11 & 11 / 07 / 11 \\ 6.2 & 2.0 & 1.028 \mathrm{E}-03 & 3.1 \% & 3 & 11 / 08 / 11 & 11 / 08 / 11 \\ 6.2 & 1.5 & 7.922 \mathrm{E}-04 & 3.1 \% & 3 & 11 / 08 / 11 & 11 / 08 / 11 \\ 6.2 & 1.0 & 5.187 \mathrm{E}-04 & 3.1 \% & 3 & 11 / 07 / 11 & 11 / 07 / 11 \\ 6.2 & 0.5 & 2.017 \mathrm{E}-04 & 3.1 \% & 3 & 11 / 08 / 11 & 11 / 08 / 11\end{array}$

Table A-7. FGMS \#1 efficiency measurements using ${ }^{85} \mathrm{Kr}(390.81 \mu \mathrm{Ci}, 80514-370)$ source transferred back from the FGMS CT\#2 (indirect) using a helium flow of $1.0 \mathrm{~L} / \mathrm{m}$ (HFEF). A systematic uncertainty of $2 \%$ was added to the statistical uncertainty.

\begin{tabular}{cccccccc}
\hline Distance & Collimator $(\mathrm{cm})$ & Efficiency & Uncertainty & $\begin{array}{c}\text { Measure- } \\
\text { ments }\end{array}$ & $\begin{array}{c}\text { First Data } \\
\text { Taken }\end{array}$ & $\begin{array}{c}\text { Last Data } \\
\text { Taken }\end{array}$ & $\begin{array}{c}\text { Gain-Transfer } \\
\text { from CT\#2 vs. } \\
\text { from FACS }\end{array}$ \\
\hline 0 & 11.0 & $4.121 \mathrm{E}-03$ & $3.2 \%$ & 3 & $11 / 09 / 11$ & $11 / 09 / 11$ & $1.8 \%$ \\
3.1 & 11.0 & $2.050 \mathrm{E}-03$ & $3.1 \%$ & 3 & $11 / 09 / 11$ & $11 / 09 / 11$ & $2.0 \%$ \\
3.1 & 2.5 & $1.605 \mathrm{E}-03$ & $3.1 \%$ & 3 & $11 / 09 / 11$ & $11 / 09 / 11$ & $4.3 \%$ \\
3.1 & 2.0 & $1.334 \mathrm{E}-03$ & $3.1 \%$ & 3 & $11 / 09 / 11$ & $11 / 09 / 11$ & $3.6 \%$ \\
3.1 & 1.5 & $9.931 \mathrm{E}-04$ & $3.1 \%$ & 3 & $11 / 09 / 11$ & $11 / 09 / 11$ & $2.7 \%$ \\
3.1 & 1.0 & $6.238 \mathrm{E}-04$ & $3.2 \%$ & 3 & $11 / 09 / 11$ & $11 / 09 / 11$ & $4.7 \%$ \\
3.1 & 0.5 & $2.263 \mathrm{E}-04$ & $3.9 \%$ & 1 & $11 / 09 / 11$ & $11 / 09 / 11$ & $7.1 \%$ \\
6.2 & 11.0 & $1.160 \mathrm{E}-03$ & $3.0 \%$ & 3 & $11 / 09 / 11$ & $11 / 09 / 11$ & $0.4 \%$ \\
\hline
\end{tabular}

\section{Estimation of FGMS \#2 ${ }^{85} \mathrm{Kr}$ Efficiency}

Table A-8. Estimating ${ }^{85} \mathrm{Kr}$ efficiency for FGMS \#2 using the source transfer from FGMS\#1 (Table A-7) and the gain from FGMS\#1 to estimate a direct transfer. 


\begin{tabular}{ccccc}
\hline $\begin{array}{c}\text { TEM-10300-1, Rev. 8 } \\
11 / 20 / 2019\end{array}$ & \multicolumn{5}{c}{ TECHNICAL EVALUATION } \\
& Fission Gas Monitoring System Efficiency Calibration Summary Report \\
\hline 0 & 11.0 & $5.057 \mathrm{E}-03$ & $4.9 \%$ & $1.8 \%$ \\
3.1 & 11.0 & $2.500 \mathrm{E}-03$ & $5.3 \%$ & $2.0 \%$ \\
3.1 & 2.5 & $1.889 \mathrm{E}-03$ & $5.3 \%$ & $4.3 \%$ \\
3.1 & 2.0 & $1.560 \mathrm{E}-03$ & $5.3 \%$ & $3.6 \%$ \\
3.1 & 1.5 & $1.152 \mathrm{E}-03$ & $5.3 \%$ & $2.7 \%$ \\
3.1 & 1.0 & $7.193 \mathrm{E}-04$ & $5.4 \%$ & $4.7 \%$ \\
3.1 & 0.5 & $2.590 \mathrm{E}-04$ & $5.9 \%$ & $7.1 \%$ \\
6.2 & 11.0 & $1.479 \mathrm{E}-03$ & $5.3 \%$ & $0.4 \%$ \\
6.2 & 2.5 & $1.200 \mathrm{E}-03$ & $8.0 \%$ & $2.0 \%$ \\
6.2 & 2.0 & $1.008 \mathrm{E}-03$ & $8.0 \%$ & $2.0 \%$ \\
6.2 & 1.5 & $7.766 \mathrm{E}-04$ & $8.0 \%$ & $2.0 \%$ \\
6.2 & 1.0 & $5.085 \mathrm{E}-04$ & $8.0 \%$ & $2.0 \%$ \\
6.2 & 0.5 & $1.977 \mathrm{E}-04$ & $8.0 \%$ & $2.0 \%$ \\
\hline
\end{tabular}

Fission Gas Monitoring System Efficiency Calibration Summary Report 


\section{Appendix B}

\section{Calculation of Efficiency and Its Uncertainty ${ }^{1}$}

From the activity equation:

$$
\operatorname{Activity}(B q)_{T_{r e f}}=\frac{n_{T_{r e f}}}{\varepsilon * p}
$$

Efficiency $(\varepsilon)$ :

$$
\varepsilon=\frac{n_{T_{r e f}}}{\operatorname{Activity}(B q)_{T_{r e f}} * p}=\frac{n_{T o C} * D C}{\operatorname{Activity}(B q)_{T_{r e f}} * p}
$$

where

$\boldsymbol{n}_{T_{r e f}}$ is the count per second at the reference date.

$$
\boldsymbol{n}_{\text {Toc }}=\frac{\text { Area }}{L T}
$$

Area $=$ fitted peak area (number of gamma rays detected)

$\mathrm{LT}=$ live time (seconds)

p for ${ }^{133} \mathrm{Xe}(81 \mathrm{keV})$ emission probability is $38.0 \%$.

$\mathrm{p}$ for ${ }^{85} \mathrm{Kr}(514 \mathrm{keV})$ emission probability is $0.434 \%$.

$\mathrm{DC}$ is the decay correction:

$$
D C=\frac{\lambda * R T}{\exp (-\lambda * \Delta T)-\exp [-\lambda *(\Delta T+R T)]}
$$

where

$$
\lambda=\frac{\ln (2)}{t_{1 / 2}}
$$

$t_{1 / 2}=$ NIST half-life for ${ }^{133} \mathrm{Xe}$ is $5.2474+/-0.0005$ days - converted to seconds

$t_{1 / 2}=$ NIST half-life for ${ }^{85} \mathrm{Kr}$ is $10.752+/-0.01$ years - converted to seconds

$\mathrm{RT}=$ real time (seconds)

$\Delta T=T$ ime in seconds from acquisition time to $T_{\text {ref }}$ 
Fission Gas Monitoring System Efficiency Calibration Summary Report

$$
\sigma_{\varepsilon}=\varepsilon * \sqrt{\frac{\sigma_{A r e a}^{2}}{A r e a^{2}}+\frac{\sigma_{D C}^{2}}{D C^{2}}+\frac{\sigma_{A c t_{T_{r e f}}}^{2}(d p m)}{A c t_{T_{r e f}}(d p m)^{2}}}
$$

where

$$
\begin{gathered}
\sigma_{\text {Area }}=\text { uncertainty in } f \text { it area, including the Poisson counting } \\
\qquad \sigma_{A c t_{\text {ref }}}(\text { dpm }) \\
=\text { uncertainty in Activity } \\
\sigma_{D C}^{2}=\frac{1}{t_{1 / 2}} *[\ln (2) * \Delta T]^{2} * \sigma_{t_{1 / 2}}^{2}
\end{gathered}
$$

where

$$
\begin{aligned}
\sigma_{t_{1 / 2}}\left({ }^{133} \mathrm{Xe}\right) & =43.2 \text { seconds } \\
\sigma_{t_{1 / 2}}\left({ }^{85} \mathrm{Kr}\right) & =3.156 E 5 \text { seconds }
\end{aligned}
$$




\section{Appendix C Radionuclide Source Certificate of Calibration}

\section{Eckert \& Ziegler}

Analytics
1380 Seaboard Industrial Blvd.

Atlanta, Georgia 30318

Tel $404 \cdot 352 \cdot 8677$

Fax $404 \cdot 352 \cdot 2837$

www.analyticsinc.com

CERTIFICATE OF CALIBRATION

Standard Radionuclide Source

80860-370

Xe-133 Gas Standard in $33 \mathrm{~mL}$ Glass Sphere

Customer: INL/Battelle Energy Alliance, LLC (DOE)

P.O. No.: $\quad 00092178$, Item I (0000166052 4)

This standard radionuclide source was calibrated by comparison to NIST traceable standards in the same geometry using a germanium gamma spectrometer system. This standard was examined for interfering gamma ray emitting impurities using a germanium gamma spectrometer system. At the time of calibration no interfering gamma emmitting impurities could be detected. Eckert \& Ziegler Analytics (EZA) maintains traceability to the National Institute of Standards and Technology through a Measurements Assurance Program as described in USNRC Regulatory Guide 4.15, Revision 1, February, 1979, and compliance with ANSI N42.22-1995, "Traceability of Radioactive Sources to NIST." EZA is accredited by the Health Physics Society (HPS) for the production of NIST-traceable sources, and this source was produced in accordance with the HPS accreditation requirements. Customers may report any concerns with the accreditation program to the HPS Secretariat, 1313 Dolley Madison Blvd., Ste. 402, McLean, VA 22101.

Calibration Date: November 17, 2009 12:00 EST

\begin{tabular}{cccccc} 
& & & & \multicolumn{3}{c}{ Uncertainty Type (\%) } \\
Isotope & Activity $(\mathrm{Bq})$ & Half-Life & $\mathrm{u}_{\mathrm{A}}$ & $\mathrm{u}_{\mathrm{B}}$ & $\mathrm{U}$ \\
\hline $\mathrm{Xe}-133$ & $8.361 \mathrm{E}+05$ & 5.243 days & 0.04 & 1.70 & 3.40
\end{tabular}

Uncertainty: U - Relative expanded uncertainty, k=2. See NIST Technical Note 1297, "Guidelines for Evaluating and Expressing the Uncertainty of NIST Measurement Results."

Comments:

Total volume of sphere 2095 including septum side arm is $32.38 \mathrm{cc}$.

Source Calibrated By:

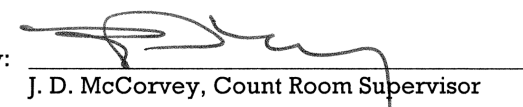

QA Approved:

$$
\mathrm{mm} p
$$

D. M. Montgomery, QA Manager

Date: $11-16-09$

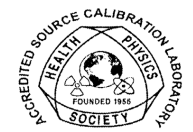

End of Certificate

Corporate Office

24937 Avenue Tihhitts Valencia. California 91355
Laboratory

1380 Seaboard Industrial Blvd. Atlanta, Georqia, 30318

Figure C-1. Certificate of calibration for ${ }^{133} \mathrm{Xe}(22.57 \mu \mathrm{Ci})$ used at FCF. 


\section{Eckert \& Ziegler}

Analytics
1380 Seaboard Industrial Blvd.

Atlanta, Georgia 30318

Tel $404 \cdot 352 \cdot 8677$

Fax $404 \cdot 352 \cdot 2837$

www.analyticsinc.com

\section{CERTIFICATE OF CALIBRATION}

Standard Radionuclide Source

\section{1-370}

Xe-133 Gas Standard in $33 \mathrm{~mL}$ Glass Sphere

Customer: INL/Battelle Energy Alliance, LLC (DOE)

P.O. No.: $\quad 00092178$, Item 2 (0000166053 4)

This standard radionuclide source was calibrated with an ionization chamber that was calibrated by the National Physical Laboratory, Teddington, U.K., and is directly traceable to national standards. Eckert \& Ziegler Analytics (EZA) maintains traceability to the National Institute of Standards and Technology through a Measurements Assurance Program as described in USNRC Regulatory Guide 4.15, Revision 1, February, 1979, and compliance with ANSI N42.22-1995, "Traceability of Radioactive Sources to NIST." EZA is accredited by the Health Physics Society (HPS) for the production of NISTtraceable sources, and this source was produced in accordance with the HPS accreditation requirements. Customers may report any concerns with the accreditation program to the HPS Secretariat, 1313 Dolley Madison Blvd., Ste. 402, McLean, VA 22101.

Calibration Date: November 17, 2009 12:00 EST

\begin{tabular}{cccccc} 
& & & & \multicolumn{3}{c}{ Uncertainty Type (\%) } \\
Isotope & Activity (Bq) & Half-Life & $\mathrm{u}_{\mathrm{A}}$ & $\mathrm{u}_{\mathrm{B}}$ & $\mathrm{U}$ \\
\hline Xe-133 & $7.880 \mathrm{E}+06$ & 5.243 days & 0.06 & 1.50 & 3.00
\end{tabular}

Uncertainty: U - Relative expanded uncertainty, k=2. See NIST Technical Note 1297, "Guidelines for Evaluating and Expressing the Uncertainty of NIST Measurement Results."

Comments:

Total volume of sphere 3129 including septum side arm is $32.16 \mathrm{cc}$.

Source Calibrated By:

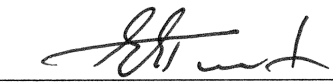

E. A. Taskaev, Production Manager

QA Approved:
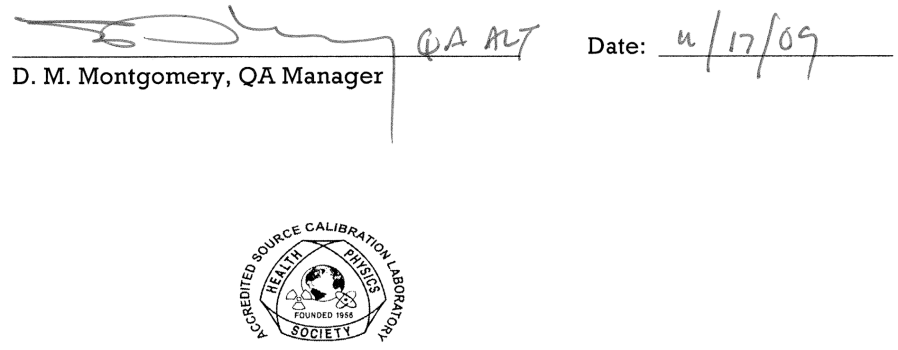

End of Certificate

Corporate Office

24937 Avenue Tibbitts Valencia.California 91355
Laboratory

1380 Seaboard Industrial Blvd. Atlanta, Georgia, 30318

Figure C-2. Certificate of calibration for ${ }^{133} \mathrm{Xe}(212.76 \mu \mathrm{Ci})$ used at FCF. 
Eckert \& Ziegler

Analytics
1380 Seaboard Industrial Blvd.

Atlanta, Georgia 30318

Tel $404 \cdot 352 \cdot 8577$

Fax $404 \cdot 352 \cdot 2837$

www.analyticsinc.com

\title{
CERTIFICATE OF CALIBRATION
}

Standard Radionuclide Source

\begin{abstract}
80511-370
Ir-85 Gas Standard in $33 \mathrm{~mL}$ Glass Sphere

Customer: INL/Battelle Energy Alliance (DOE)

P.O. No.: $\quad 00089165$ Rev 1, Item 1 (0000165218 4)

This standard radionuclide source was calibrated by comparison to NIST traceable standards in the same geometry using a germanium gamma spectrometer system. This standard was examined for interfering gamma ray emitting impurities using a germanium gamma spectrometer system. At the time of calibration no interfering gamma emmitting impurities could be detected. Eckert \& Ziegler Analytics (EZA) maintains traceability to the National Institute of Standards and Technology through a Measurements Assurance Program as described in USNRC Regulatory Guide 4.15, Revision 1 , February, 1979, and compliance with ANSI N42.22-1995, "Traceability of Radioactive Sources to NIST." EZA is accredited by the Health Physics Society (HPS) for the production of NIST-traceable sources, and this source was produced in accordance with the HPS accreditation requirements. Customers may report any concerns with the accreditation program to the HPS Secretariat, I313 Dolley Madison Blvd., Ste. 402, McLean, VA. 22101.
\end{abstract}

Calibration Date: September 23, 2009 12:00 PM EST

\begin{tabular}{cccccc} 
Isotope & Activity $(\mathrm{Bq})$ & Half-Life & $\mathrm{u}_{\mathrm{A}}$ & $\begin{array}{c}\text { Uncertainty*, } \\
\text { Type } \\
\mathrm{v}_{\mathrm{B}}\end{array}$ & $\mathrm{U}$ \\
\hline $\mathrm{Kr}-85$ & $3.418 \mathrm{E}+04$ & 10.752 years & 0.28 & 1.7 & 3.4
\end{tabular}

*Uncertainty: U - Relative expanded uncertainty, k=2. See NIST Technical Note 1297, "Guidelines for Evaluating and Expressing the Uncertainty of NIST Measurement Results."

Comments:

Total volume of sphere 1376 including septurn side arm is $32.41 \mathrm{cc}$.

Source Calibrated By:

QA Approved:

Date: $9-23-0 q$

D. M. Montgomely, QA Manager

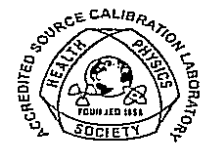

Cornorate Office

Figure C-3. Certificate of calibration for ${ }^{85} \mathrm{Kr}(0.924 \mu \mathrm{Ci})$ used at FCF. 
Fission Gas Monitoring System Efficiency Calibration Summary Report

\section{Eckert \& Ziegler}

Analytics
1380 Seaboard Industrial Blvd. Atlanta, Georgia 30318 Tel $404 \cdot 352 \cdot 8677$ Fax $404 \cdot 352 \cdot 2837$ www.analyticsinc.com

\section{CERTIFICATE OF CALIBRATION}

Standard Radionuclide Source

$$
\text { 80512-370 }
$$

$\mathrm{Kr}-85$ Gas Standard in $33 \mathrm{~mL}$ Glass Sphere

Customer: INL/Battelle Energy Alliance (DOE)

P.O. No.: $\quad 00089165$ Rev 1, Item 2 (0000165220 4)

This standard radionuclide source was calibrated by comparison to NIST traceable standards in the same geometry using a germanium gamma spectrometer system. This standard was examined for interfering gamma ray emitting impurities using a germanium gamma spectrometer system. At the time of calibration no interfering gamma emmitting impurities could be detected. Eckert \& Ziegler Analytics (EZA) maintains traceability to the National Institute of Standards and Technology through a Measurements Assurance Program as described in USNRC Regulatory Guide 4.15, Revision 1, February, 1979, and compliance with ANSI N42.22-1995, "Traceability of Radioactive Sources to NIST." EZA is accredited by the Health Physics Society (HPS) for the production of NIST-traceeble sources, and this source was produced in accordance with the HPS accreditation requirements. Customers may report any concerns with the accreditation program to the HPS Secretariat, 1313 Dolley Madison Blvd., Ste. 402, McLean, VA 22101.

Calibration Date: September 23, 2009 12:00 PM EST

\begin{tabular}{cccccc} 
& & & \multicolumn{3}{c}{ Uncertainty*, (\%) $_{\text {Type }}$} \\
Isotope & Activity $(\mathrm{Bq})$ & Half-Iife & $\mathrm{u}_{\mathrm{A}}$ & $\mathrm{u}_{\mathrm{B}}$ & $\mathrm{U}$ \\
\hline $\mathrm{IKT}-85$ & $3.819 \mathrm{E}+05$ & 10.752 years & 1.0 & 1.7 & 3.9
\end{tabular}

*Uncertainty: U - Relative exparded uncertainty, $k=2$. See NIST Technical Note 1297, "Guidelines for Evaluating and Expressing the Uncertainty of NIST Measurement Results."

Comments:

Total volume of sphere 1361 including septum side arm is $32.14 \mathrm{cc}$.

Source Calibrated By:

QA Approved:

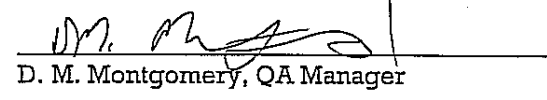

Date: $\quad 9-23-09$

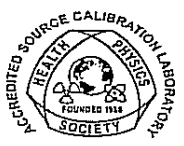

Corporate Office

Laboratory

24937 Avenue Tibbitts Valencia, Californla 91355

1380 Seaboard industrial Blvd. Atlanta, Georgia, 30318

Figure C-4. Certificate of Calibration for ${ }^{85} \mathrm{Kr}$ (about $10 \mu \mathrm{Ci}$ ) used at FCF. 


\section{Eckert \& Ziegler} Analytics
1380 Seaboard Industrial Blvd. Atlanta, Georgia 30318

Tel $404 \cdot 352 \cdot 8677$

Fax 404.352.2837

www.analyticsinc.com

\section{CERTIFICATE OF CALIBRATION} Standard Radionuclide Source

80513-370

Kr-85 Gas Standard in $33 \mathrm{~mL}$ Glass Sphere

Customer: $\quad$ INL/Battelle Energy Alliance (DOE)

P.O. No.: $\quad 00089165$ Rev l, Item $3(00001652214)$

This standard radionuclide source was calibrated by comparison to NIST traceable standards in the same geometry using a germarium gamma spectrometer system. This standard was examined for interfering ganuma ray emitting impurities using a germanium gamma spectrometer system. At the time of calibration no interfering gamma emmitting impurities could be detected. Eckert \& Ziegler Analytics (EZA) maintains traceability to the National Institute of Standards and Technology through a Measurements Assurance Program as described in USNRC Regulatory Guide 4.15, Revision $1_{1}$ February, 1979, and compliance with ANSI N42.22-1995, "Traceability of Radioactive Sources to NIST." EZA is accredited by the Health Physics Society (HPS) for the production of NIST-traceable sources, and this source was produced in accordance with the HPS accreditation requirements. Customers may report any concerns with the accreditation program to the HPS Secretariat, 1313 Dolley Madison Blvd., Ste. 402, McLean, VA 22101.

Calibration Date: September 23, 2009 12:00 PM EST

\begin{tabular}{cccccc} 
& & & \multicolumn{3}{c}{ Uncertainty*, (\%) $_{\text {Type }}$} \\
Isotope & Activity $(\mathrm{Bq})$ & Half-Ijife & $\mathfrak{u}_{\mathrm{A}}$ & $\mathrm{u}_{\mathrm{B}}$ & $\mathrm{U}$ \\
\hline $\mathrm{Kr} r-85$ & $3.846 \mathrm{E}+06$ & 10.752 years & 1.4 & 1.7 & 5.6
\end{tabular}

*Uncertainty: U - Relative expanded uncertainty, $k=2$. See NIST Techrical Note 1297, "Guidelines for Evaluating and Expressing the Uncertainty of NIST Measurement Results."

Comments:

Total volume of sphere 3022 including septum side arm is $30.24 \mathrm{cc}$.

Source Calibrated By:

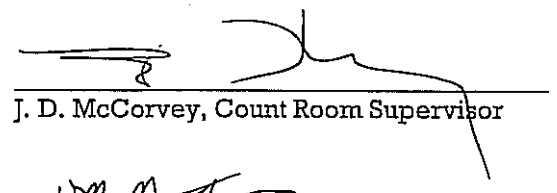

QA Approved:

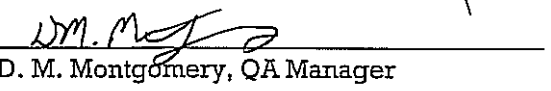

Date: $9-23-09$

$$
\text { D. M. Montgomery, QA Marager }
$$

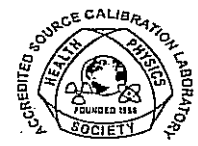

Figure C-5. Certificate of calibration for ${ }^{85} \mathrm{Kr}(103.95 \mu \mathrm{Ci})$ used at FCF. 


\section{Eckert \& Ziegler}

Analytics
1380 Seaboard Industrial Blvd. Atlanta, Georgia 30318

Tel $404 \cdot 352 \cdot 8677$

Fax $404 \cdot 352 \cdot 2837$

www.analyticsinc.com

\title{
CERTIFICATE OF CALIBRATION
}

Standard Radionuclide Source

\begin{abstract}
$80514-370$
Kr-85 Gas Staridard in $33 \mathrm{~mL}$ Glass Sphere

Customer: INL/Battelle Energy Alliarce (DOE)

P.O. No.: $\quad 00089165$ Rev l, Item 4 (0000165222 4)

This standard radionuclide source was calibrated by comparison to NIST traceable standards in the same geometry using a germanium gamma spectrometer system. This standard was examined for interfering gamma ray emitting impurities using a germanium gamma spectrometer system. At the time of calibration no interfering gamma emmitting impurities could be detected. Eckert \& Ziegler Analytics (EZA) maintains traceability to the National Institute of Standards and Technology through a Measurements Assurance Program as described in USNRC Regulatory Guide 4.15, Revision I, February, 1979, and compliance with ANSI N42.22-1995, "Traceability of Radioactive Sources to NIST." EZA is accredited by the Health Physics Society (HPS) for the production of NIST-traceable sources, and this source was produced in accordance with the HPS accreditation requirements. Customers may report any concerns with the accreditation program to the HPS Secretariat, 1313 Dolley Madison Blvd., Ste. 402, McLean, VA 22101.
\end{abstract}

Calibration Date: September 23, 2009 12:00 PM EST

\begin{tabular}{cccccc} 
& & & \multicolumn{3}{c}{ Uncertainty*, (\%) } \\
Isotope & Activity (Bq) & Half-Iife & $\mathrm{u}_{\mathrm{A}}$ & $\mathrm{u}_{\mathrm{B}}$ & $\mathrm{U}$ \\
\hline $\mathrm{Kr}-85$ & $1.446 \mathrm{E}+07$ & 10.752 years & 0.5 & 1.7 & 4.9
\end{tabular}

*Uncertainty: U - Relative expanded uncertainty, $k=2$. See NIST Techrical Note 1297, "Guidelines for Evaluating and Expressing the Uncertainty of NIST Measurement Results."

Comments:

Total volume of sphere 2660 including septum side arm is $32.50 \mathrm{cc}$.

Source Calibrated By: $\frac{8}{\text { J.D.McCorvey, Count Room Supervisor }}$

QA Approved:

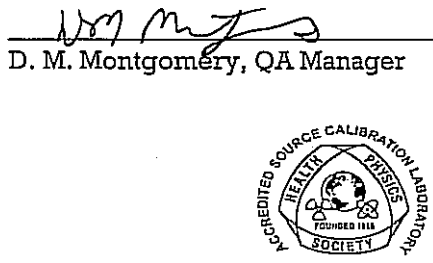

Date: $9-23-09$

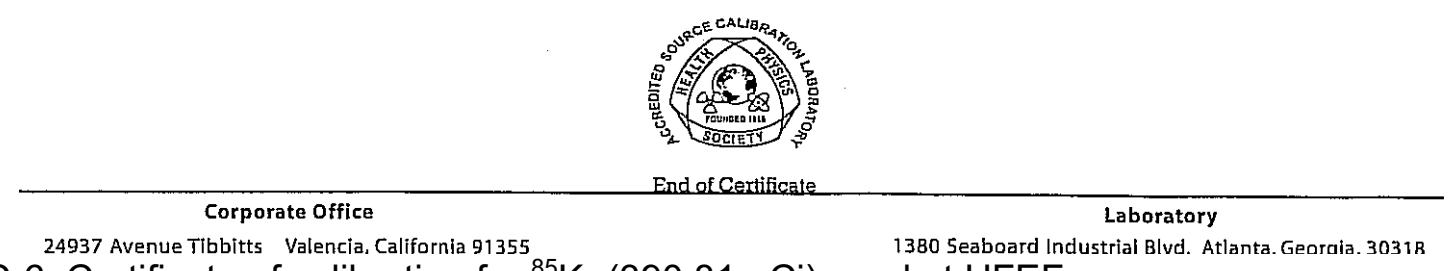

Figure C-6. Certificate of calibration for ${ }^{85} \mathrm{Kr}(390.81 \mu \mathrm{Ci})$ used at HFEF. 